\title{
Additionality as a principle of European R\&D funding
}

Citation for published version (APA):

David, P. A., Steinmueller, W. E., \& geuna, A. (1995). Additionality as a principle of European R\&D

funding. MERIT, Maastricht Economic Research Institute on Innovation and Technology. MERIT

Research Memoranda No. 009 https://doi.org/10.26481/umamer.1995009

Document status and date:

Published: 01/01/1995

DOI:

10.26481/umamer.1995009

Document Version:

Publisher's PDF, also known as Version of record

\section{Please check the document version of this publication:}

- A submitted manuscript is the version of the article upon submission and before peer-review. There can be important differences between the submitted version and the official published version of record.

People interested in the research are advised to contact the author for the final version of the publication, or visit the DOI to the publisher's website.

- The final author version and the galley proof are versions of the publication after peer review.

- The final published version features the final layout of the paper including the volume, issue and page numbers.

Link to publication

\footnotetext{
General rights rights.

- You may freely distribute the URL identifying the publication in the public portal. please follow below link for the End User Agreement:

www.umlib.nl/taverne-license

Take down policy

If you believe that this document breaches copyright please contact us at:

repository@maastrichtuniversity.nl

providing details and we will investigate your claim.
}

Copyright and moral rights for the publications made accessible in the public portal are retained by the authors and/or other copyright owners and it is a condition of accessing publications that users recognise and abide by the legal requirements associated with these

- Users may download and print one copy of any publication from the public portal for the purpose of private study or research.

- You may not further distribute the material or use it for any profit-making activity or commercial gain

If the publication is distributed under the terms of Article $25 \mathrm{fa}$ of the Dutch Copyright Act, indicated by the "Taverne" license above, 


\title{
ADDITIONALITY AS A PRINCIPLE OF EUROPEAN R\&D FUNDING
}

\author{
FINAL REPORT
}

\author{
A Study carried out for the STOA programme \\ of the European Parliament.
}

The document in its present stage does not reflect the official views of the STOA programme or the European Parliament. It is being circulated for comment and is not the final publication of the Report, which will be issued by STOA for the European Parliament.

by

P.A. David, All Souls College, University of Oxford

A.Geuna, MERIT, University of Limburg

W.E. Steinmueller, MERIT, University of Limburg

14 June, 1995

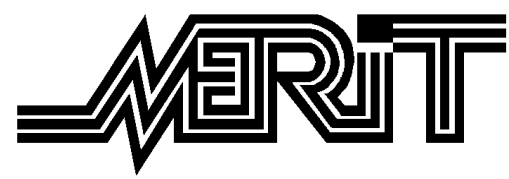

Maastricht Economic Research Institute On Innovation and Technology, University of Limburg, P.O. Box 616, 6200 MD Maastricht, The Netherlands, Tel. 31 (0) 43 883865, Fax. 31 (0) 43 216518, A.Geuna@MERIT.Rulimburg.NL 


\section{Acknowledgments}

We are grateful for the guidance and support Glyn Ford, MEP, and for the data supplied by the services of the European Commission. 


\section{Contents}

\section{EXECUTIVE SUMMARY}

1. INTRODUCTION

2. EU SCIENCE AND TECHNOLOGY POLICY, ADDITIONALITY VERSUS SUBSTITUTION EFFECTS

3. AN OVERVIEW OF SUBSTITUTION EFFECTS WITHIN THE EU

4. UNIVERSITY PARTICIPATION IN COMMUNITY PROGRAMMES

4.1 BRITE-EURAM and the United Kingdom case

5. UNITED KINGDOM UNIVERSITIES, FUNDING MECHANISMS AND EU IMPACT

5.1 The aggregate situation

5.2 Department analysis

6. CONCLUSIONS

ANNEX (A): EU, Research Council and Total Income to UK Universities ANNEX (B): Telephone interview and questionnaire ANNEX (C): List of Framework Programmes taken into account

REFERENCES 


\section{Executive summary}

This report summarises an analysis of the impact of EU funding on the allocative decisions of member state governments and research organisations. Among the principal contributions of this report are the following:

1. An economic theory of the aims of additionality as a principle in the allocation of EU funds.

2. A broad definition of additionality based on this theory.

3. A narrow or financial definition of additionality related to the evaluation of funds allocation by member states in EU programmes.

4. An examination of university participation in EU programmes generally, and the BRITE-EURAM programme in specific.

5. An analysis of the changes in the financing of higher education institutions during the past decade in one member state, the UK, that may (for better or worse) be a model for responding to fiscal stringency in other member states.

6. An application of the narrow or financial definition of additionality to the funding of UK higher education institutions, showing that additionality is generally present in the UK, but raising concern about the unintended effects of EU funding upon the allocation of national public and private research funding going to higher education institutions.

7. An analysis of the impact of EU funding among a sample of UK university departments participating in BRITE-EURAM, indicating that there are marked differences between the impacts on large departments in large universities, and on small and medium sized departments in small universities. 
"Additionality" is an important topic in the ongoing discussion of divisions of responsibility between the EU and the Member States in which EU roles are sought that will augment and improve the welfare of Europeans. Additionality is used in this report in two senses. The first, denoted here as the "principle of additionality" takes up the broader issue of how EU funding may meet the normative standard for any government action, i.e. that it leads to social or economic value less easily or less completely achieved through the action of smaller social units. The second meaning, denoted here as the "narrow" or financial definition of additionality, is concerned with the use of financial resources.

The "principle of additionality" involves using to EU funds, and here EU RTD funds, to augment or improve the outcomes available from the individual choices of member states. Thus, in the broadest sense, a goal for EU RTD funding is that it should create benefits that are greater than (additional to) those that would be available through a strictly national allocation of RTD funds within Europe. This is, of course, simply a restatement of the normative criterion that generally applies to the role of governments. It immediately leads to the question of what the EU, as a supra-national political body, can do that results in gain relative to the actions of individual member states, i.e. that is additional to member state actions?

There are at least four sets of answers to this question, each of which contributes to an understanding of the "principle of additionality." ${ }^{1}$ They include

--Realising the advantages of scale and scope obtainable through collective effort as in the construction of large scientific facilities or the assembly of complementary capabilities spanning member state boundaries.

--Addressing externalities that span member state boundaries such as RTD programmes for ameliorating negative externalities or promoting positive externalities that would induce smaller than desirable levels of effort if pursued only at the level of member states.

--Contributing to the development of the Union. Given the expectation that the EU is improving the economic and social welfare of Europeans, the EU can adopt RTD policies that help further the union, e.g., by completing the internal market or promoting cohesion within the EU.

1 A similar list is available in Commission of the European Communities (1994b) 
--Rationalizing or increasing the efficiency of national research efforts or combining these efforts to achieve more effective cooperation with national states outside the EU.

In addition to the broader aims pursued under the "principle of additionality," there are specific questions of its implementation that are the direct concern of this study. In particular, the "narrow" or financial meaning of "additionality" is an operational criterion for defining the impact of EU funding on the conduct of research efforts. The aims of this funding are to contribute an "additional" amount to the budgets, and hence efforts, of the organisations performing EU contracts within member states as well as to achieve aims according with the broader "principle of additionality." A "narrow" or financial definition of additionality is an absence or limitation in member state substitution of EU funds for their own funding support of RTD activities and institutions. Since EU RTD programmes are presumed to be additional to a base of RTD efforts in individual member states, such substitution may lead to lower than expected benefits of EU funding for the EU as a whole. This is because all RTD funding has the potential for improving welfare by generating knowledge spillovers throughout the EU. ${ }^{2}$ Hence, the EU, representing the collective interest of the member states, has a motive and rationale for monitoring the extent of substitution of EU for national funds in RTD activities and attempting to assure that both the "principle of additionality" as well as additionality in the "narrow" and financial sense occurs in RTD funding efforts.

Since the early 1980s, a major aim of Commission RTD funding has been to increase the global competitiveness of EU enterprises through support of activities that would (1) augment the impact of the single market in building technological capabilities (dynamic economies of scale) through technological convergence, (2) bolster the position of small and medium sized enterprises (particularly those enterprises that were technologically intensive), and (3) foster intra-European networks of research collaboration. These activities are all ones in which positive externalities are likely to extend across the borders of member states. At the same time, all of these activities have some counterparts in and relationships to national programmes. The distinction between EU and national efforts often has been drawn in terms of the explicit efforts of the EU to foster transnational activities. But as national governments adopt a more global perspective on problems of competition, there is unlikely to be a bright line separating EU

2 These spillover benefits continue to be generated by those countries that do not substitute EU for their own funds. Thus, the country that does substitute becomes a "free rider" on the continuing expenditures of others. We cannot, however, conclude that this necessarily lowers social and economic welfare without considering what use is made of the "released" funds. In their new deployment, they may also generate externalities that span national boundaries. 
objectives from those of member states. As a result, consideration of the coordination and complementarity between EU and member state RTD efforts have become of increasing salience in policy discussions. ${ }^{3}$

Moreover, from a practical viewpoint, the R\&D institutions that are called upon to address both national and EU needs receive funding directly from member states as well as from the EU. The existence of two streams of funds in support of research institutions, one originating directly from member states and the other originating from the EU may provide an opportunity to reduce direct member state funding, i.e. to substitute EU for national funding of R\&D institutions. To the extent that they occur, such substitutions of EU for member state allocations to R\&D institutions alter one foundation of EU funding for RTD, the assumption that it does not affect existing member state RTD allocations. Substitution means that instead of member state funding levels and purposes being fixed, they may depend upon the level and purposes of EU funding. At the level of individual institutions substitution of EU funds for member state support may occur in an implicit manner.

The relations between national and EU purposes in supporting R\&D institutions are subject to a number of complex interactions. In our present investigation, we have confined our examination of this broader feature of additionality to an analysis of the relation among broad categories of social purposes pursued by member states and the EU. Within these categories, substantial differences may exist in objectives and patterns of specialization, many of which are subject to the sort of reinforcing effects and unintended consequences that we identify in this report. Such effects are important for many reasons, including the evaluation of the effectiveness of EU programmes in achieving the goal of accelerating the convergence of scientific and technical capabilities, in fostering the competitiveness of SME, and in bolstering the competitiveness of EU business. They therefore merit considerably deeper study than we are able to provide here.

The extent of financial substitution is an empirical question. Substitution of EU for member state funding may occur at various levels including the overall allocations to domestic research organizations, among universities within member states, and, at the level of individual research organizations, among different departments. This study finds no systematic or pervasive evidence of substitution at the level of national funding of research efforts among the member states. This conclusion is, however, limited in scope. It applies only to two behavioral hypotheses about the ways in which substitution would take place. The first is that substitution occurs contemporaneously and should be observable as a negative correlation between changes in the level of estimated EU funding and changes

\footnotetext{
${ }^{3}$ See Commission of the European Communities, 1994c.
} 
in budgeted member state funding. The second is that such a negative correlation occurs with a lag (i.e. the hypothesis that substitution occurs in response to changes in the preceding year of the level of estimated EU funding). Other, more complicated, substitution effects cannot be directly tested with the data that presently are available to us. For example, the extent to which government financing would have increased but for EU funding is not possible to examine by indirect, purely statistical methods, without imposing rigid and unrealistic assumptions about the pattern of growth of member state R\&D funding.

At the level of individual universities and university departments we do find evidence of substitution relationships. These, however, are complicated by the so-called "Matthew effect", whereby previous awards of funding tends to increase the probability of future funding success. This conclusion, based on a survey of the funding of UK higher education institutions in the areas impacted by the Brite-Euram programme, indicates that substitution is likely to occur at the level of smaller and medium sized institutions, whereas among larger institutions, the impact of EU funding is primarily that of creating positive reinforcement effects. Thus, an important conclusion of our study is that EU funding may have unintended consequences for the allocation of research funds among universities and among the research activities pursued by specific departments within universities.

\section{Recommendations/Action Items:}

Based on the conclusions of our study, our principal recommendations are:

-- The European Commission and the Parliament should continue to monitor the extent of additionality in RTD programmes. Specifically, this implies:

-- A continuing review of the coordination between EU and member state RTD initiatives to enhance and augment the beneficial spillovers from these initiatives throughout the Union.

-- $\quad$ Gathering further information about implicit and explicit practices of "attribution" of EU RTD funds in the fiscal policies of member states.

-- The European Commission and the Parliament should continue to monitor the possibilities of "unintended consequences" in the distribution of the EU RTD funds 
including the possibilities of unintentionally reinforcing the advantages of larger institutions or member states.

In addition, a more definitive conclusion about the location and extent of financial additionality issues would require:

-- Developing a method for tracing the final allocation of funding across member states within the subcontracting structure encouraged by current RTD policies.

-- $\quad$ Further developing indicators of the impact on institutional behaviour of the receipt of EU funds.

Each of these two recommendations should be qualified by the difficulty or expense of implementation. Given our main finding, that financial additionality is not a systematic or pervasive problem, and our collateral conclusion, that financial additionality may be an issue at the level of individual institutions, it may be more appropriate to focus attention on the specific problems of smaller or more specialized institutions. 


\section{Introduction}

Although the "principle of additionality" may eventually have a narrow and precise definition, it currently has several distinct meanings. Our aim has been to refine the definition of additionality, first by distinguishing between the broad meaning of the "principle of additionality" and a "narrow" or financial meaning of additionality related to the use of funds allocated to RTD activities. We consider the application of the concept from the largest unit of analysis, the relation of the EU and member states with regard to RTD funding under the Second and Third Framework Programmes, to one of the smallest, that is, the allocation of funds at the level of higher education institution departments. To perform this analysis within the scope of the contract (STOA/DG4B/RCT/ADDITIONALITY) between STOA and MERIT, we begin with an overview of data at the EU level and then progressively narrow the analysis to a single programme (BRITE-EURAM), a single member state (the United Kingdom) and, finally to a subset of UK higher education institutions (a sample of U.K. university departments participating in the BRITE-EURAM programme).

Among the principal contributions of this report are the following:

1. An economic theory of the aims of additionality as a principle in the allocation of EU funds.

2. A broad definition of additionality based on this theory.

3. A narrow or financial definition of additionality related to the evaluation of funds allocation by member states in EU programmes.

4. An examination of university participation in EU programmes generally, and the BRITE-EURAM programme in specific.

5. An analysis of the changes in the financing of higher education institutions during the past decade in one member state, the UK, that may (for better or 
worse) be a model for responding to fiscal stringency in other member states.

6. An application of the narrow or financial definition of additionality to the funding of UK higher education institutions, showing that additionality is generally present in the UK, but raising concern about the unintended effects of EU funding upon the allocation of national public and private research funding going to higher education institutions.

7. An analysis of the impact of EU funding among a sample of UK university departments participating in BRITE-EURAM, indicating that there are marked differences between the impacts on large departments in large universities, and on small and medium sized departments in small universities.

EU RTD funding is driven by competing policy aims. A better understanding of the individual contribution of each of these aims can be achieved by developing measures that make it possible to distinguish among them. In addition, policy decisions may result in unintended or conflicting outcomes. Future policy decisions will benefit from an improved understanding of the contribution of each of the several meanings of "additionality" to policy outcomes. 


\section{EU Science and Technology Policy, Additionality versus Substitution Effects}

"Additionality" is an important topic in the ongoing discussion of divisions of responsibility between the EU and the Member States in which EU roles are sought that will augment and improve the welfare of Europeans. As we will note below, there is a "narrow" or financial definition of "additionality" related to the use of financial resources. It is worth considering, however, whether there is a broader "principle of additionality" that should inform us about the "additional" role for EU funding of research and technology development (RTD) efforts within member states that already have their own RTD programmes. RTD funding by the EU is based on the idea that this means of organising funding will augment or improve the outcomes available from the individual choices of member states. Thus, in the broadest sense, a goal for EU RTD funding is that it should create benefits that are greater than (additional to) those that would be available through a strictly national allocation of RTD funds within Europe. This is, of course, nothing more than the normative criterion that generally applies to the role of governments. It immediately leads to the question of what the EU, as a supra-national political body, can do that results in gain relative to the actions of individual member states, i.e. that is additional to member state actions?

There are at least four sets of answers to this question, each of which contributes to an understanding of the "principle of additionality." 4 The first set of answers have to do with realising the advantages of scale and scope obtainable through collective effort. The EU may undertake initiatives that would be too large for individual member states (and that are not easily divisible) or that would create synergies by combining complementarities spanning member state boundaries within the Union. The second set of answers have to do with addressing externalities that span national boundaries. Because positive and negative externalities may span member state boundaries, the incentives of individual member states, acting on behalf of their own citizens, to enhance or ameliorate these externalities may be insufficient to generate the optimal level of investment for Europe as a whole (the sum of individual actions may be smaller than optimal). The EU,

\footnotetext{
4 A similar list is available in Commission of the European Communities (1994b)
} 
acting in the collective interest, may be able to achieve a higher level of social and economic welfare than would follow from the independent actions of member states, leading to a clear benefit from collective funding. The third set of answers have to do with the contributory role of RTD policies to the development of the Union. Given the expectation that the EU is improving the economic and social welfare of Europeans, the EU can adopt RTD policies that help further the union by, e.g., completing the internal market or promoting cohesion within the EU. The fourth, and final, set of answers, have to do with the possibilities of rationalizing or increasing the efficiency of national research efforts or the cooperation with national states outside the EU. These opportunities involve strengthening the coordination among national RTD programmes and between EU and member state RTD programmes in order to streamline or bring together research efforts. ${ }^{5}$ In short, the EU may be able to achieve "additionality" through promotion of economies of scale and scope, addressing of externalities, promotion of the development of the EU, or coordination. Collectively, these rationales offer an operational "principle of additionality" by which EU RTD actions may further European social and economic welfare.

In addition to the broader aims pursued under the "principle of additionality," there are specific questions of its implementation that are the direct concern of this study. In particular, the "narrow" or financial meaning of "additionality" is an operational criterion for defining the impact of EU funding on the conduct of research efforts. The aims of this funding are to contribute an "additional" amount to the budgets, and hence efforts, of the organisations performing EU contracts within member states as well as achieving aims that accord with the broader "principle of additionality." A "narrow" or financial definition of additionality is an absence or limitation in member state substitution of EU funds for their own funding support of RTD activities and institutions. The "narrow" or financial definition of additionality is, in fact, a partially independent goal from the principle of additionality because it takes into account the possibility of independent responses of member states to EC RTD funding. If, acting independently, member states were to substitute EU for their own funds, the first effect of this choice would be to replace the goals of national programmes with those of EU programmes. ${ }^{6}$ But, since EU RTD programmes are presumed to be additional and complementary to a base of RTD efforts in individual member states, such substitution may also lower the expected benefits for the

5 Bringing together research efforts may be particularly useful for negotiations involving international cooperation. Caution is required in streamlining and seeking economies of scale in research efforts since these objectives may sacrifice useful variety in research initiatives.

6 This assumes that EU project administration is effective in monitoring research activities, so that what is proposed is what is performed, and that funded proposals incorporate EU objectives that do not duplicate national research objectives. 
EU as a whole. This is because all RTD funding has the potential for improving welfare by generating knowledge spillovers throughout the EU. ${ }^{7}$ Hence, the EU, representing the collective interest of the member states, has a motive and rationale for monitoring the extent of substitution of EU for national funds in RTD activities and attempting to assure that both the "principle of additionality" as well as additionality in the "narrow" and financial sense occurs in RTD funding efforts. Finally, it is essential to note that the issues of financial additionality extend to lower levels of social aggregation than the nation state. Within nation states, organizations that receive funding also will consider whether the receipt of EU funds will allow them to release their own funds for other purposes, some of which may not have the same potential for European-wide spillovers as their existing research activities.

These definitions raise two distinct questions. First, what principles will assure that EU funding of RTD will not be a replacement, or a substitute, for the efforts of member states? Second, what will be the response of member states, and the institutions within those member states, to the potential or actual receipt of research funds from the EU? The issue of "additionality" emerges from at the intersection of answers to these two questions.

Principles that will assure that EU funding of research and technology development (RTD) will not be a replacement or a substitute for the efforts of member states are likely to prove elusive due to common objectives of the EU and member states. One approach, represented in a recent House of Lords Report is to attempt to define categories by which to restrict Commission funding activities. The Report came up with the following criteria for EU projects:

(i) they are directed towards the development of common standards;

(ii) they aim to solve community or international problems, such as those concerned with the environment;

(iii) they are too costly for any one Member State to undertake;

(iv) there would be added value in performing them at a Community rather than a national level.

7 These spillover benefits continue to be generated by those countries that do not substitute EU for their own funds. Thus, the country that does substitute becomes a "free rider" on the others continuing expenditures. We cannot, however, conclude that this necessarily lowers social and economic welfare without considering what use is made of the "released" funds. In their new deployment, they may also generate externalities that span national boundaries. 
From an economic viewpoint, the first two criteria are based on the assumption of the relative efficiency of central coordination and the principle that the collective benefit received by all the member states exceeds the benefits accruing to individual member states. $^{8}$ The third criteria may be related to economies of scale as well as coordination. This is clearly not an exhaustive list of the possible cases where collective benefits may exceed those received by individual member states. More generally, all activities that generate positive externalities or ameliorate negative externalities that cross member state borders may provide a justification for collective EU activity,as was not above.

At the same time, however, each of these areas may be the subject of unilateral national efforts or multilateral efforts involving fewer than all of the member states of the EU. Indeed, it would be surprising if member states were to relinquish all initiatives in any of these areas. Precisely how to define the level to which such national efforts should be augmented, and the extent to which national governments will maintain their own support of such activities given the existence of EU funding is an open question. Presumably, the willingness of member states to undertake collective actions through the EU will be subject to the perceived added value of EU initiatives, the subject of the fourth criteria offered in the House of Lords report. This fourth criteria offers a broad opening for both action and debate. The opening comes about through the breadth of possible meanings that might be attached to "added value" which might span a wide range of possible positive externalities such as those arising from the advance of scientific understanding and negative externalities such as unemployment (which, since the Treaty of Maastricht, can no longer be viewed solely as a national problem). Similarly, debate is likely to occur as to exactly how Community measures bring value that could not be achieved through the actions of a single member state.

In practice, since the early 1980s, a major aim of Commission RTD funding has been to increase the global competitiveness of EU enterprises through support of activities that would augment the impact of the single market in building technological capabilities (dynamic economies of scale) through technological cohesion, bolster the position of small and medium sized enterprises (particularly those enterprises that were technologically intensive), and foster intra-European networks of research collaboration in order to maintain or extend the capabilities of European enterprises to compete in the

\footnotetext{
${ }^{8}$ Achieving collective benefits in excess of individual benefits requires the existence of an externality that crosses national boundaries. In the case of telecommunication standards, for example, positive externalities are larger when it is possible to interconnect the networks of member states and are first received by the users of international telecommunication services. Similarly, with environmental issues, exchange between member state of negative externalities such as water pollution or of positive externalities such as better knowledge of pollution abatement technology is a pre-requisite to the realization of collective benefits.
} 
global economy. All of these activities are ones where positive externalities may span member states borders as well as boundaries between the EU and the rest of the world. ${ }^{9}$ Improving technological capabilities and the health of technologically progressive SME fosters economic integration and the benefits of improved international division of labour while intra-European research networks provide channels for knowledge spillover across national boundaries. ${ }^{10}$ At the same time, all of these activities are related to national programmes as well. The distinction between EU and national efforts has often been in terms of the explicit efforts of the EU to foster transnational activities, but as national governments adopt a more global perspective on problems of competition there is unlikely to be a bright line separating EU from member states objectives.

In the absence of a rigid boundary between Community and member states research objectives, the RTD policy of the Community can be viewed as a political outcome. The effort to define the respective activities of Community and member states in RTD may evolve as the outcome of the processes of political negotiation, practical experience, and perceived changes in needs and opportunities. While perhaps more realistic than an effort to define a "first principles" boundary between Community and member state RTD activities, defining the boundary between EU and member states activities as the outcome of a process is subject to several weaknesses.

The first, and for present purposes most significant of these weaknesses, involves the possible answers to the question; what will be the response of member states to the receipt of EU RTD funds? ${ }^{11}$ The funding needed to implement RTD policies is received from member states and then disbursed to the institutions within member states whose budgets and funding are principally within the control of member state governments. Member states, in the exercise of their own fiscal policy, can modify, either by augmentation or subtraction of national funds, any funding initiative undertaken collectively by the Community to any institution receiving significant national funds. Moreover, such financial adjustments may occur either contemporaneously with the

\footnotetext{
9 The fact that positive externalities may create global benefits suggests to some that they are not worth achieving. Aside from the fact that the EU benefits from global externalities produced by others, it is important to note that, in practice, positive externalities such as those arising from scientific and technological knowledge are imperfectly transmitted and their value is attenuated rapidly through separations of cultural and geographical difference. This is one reason why EU programs aimed at technological convergence and social cohesion have a potentially large payoff. See Soete and Arundel (1993).

10 On the economic implications of the different treatment of information in "open," academic science institutions and business-sector R\&D organisations, see Dasgupta and David (1994).

11 Other weaknesses include the possibility of delay or deadlock based on differences of opinion among member states in rapidly changing areas of technology.
} 
budgeted receipt of Community funds or over some longer time horizon. The extent to which member states use EU funds as a substitute for their own funding may then depend upon the extent to which current EU RTD policies reflect the national priorities of the member states. If EU and member states policies are consistent but the member states budgets are limited, then the member state will have less incentive to substitute national funds away from domestic institutional recipients of EU funds. In other circumstances, member states may chose to substitute EU funds for those they directly control and use the savings to meet other national funding priorities. By this mechanism, it is possible for member states to vitiate the EU aim of increasing the extent of effort in particular areas and this raises questions about whether the EU can establish priorities by majority rule rather than consensus. It is also possible that member states may promote the receipt of EU funds by investing in particular lines of research that complement EU RTD funding objectives. Thus, the independence of member states initiative may serve to augment EU RTD funding aims. ${ }^{12}$

There are, however, limits to the extent of this problem. In particular, it is not possible for member states or other recipients to make opportunistic gains at the expense of the EU as a whole, or to engage in substitution of funds without altering the activities pursued. Removing more member state funding than is received from EU funding is the same as a member state decision to reduce the funding of the receiving institution. Similarly, when private rather than public institutions are the recipients, reducing the amount of the own funds used by private institutions is a choice to reduce their level of research effort. In both cases, it is assumed that the EU is effective in assuring the use of funds for the purposes allocated, eliminating the possibility of misappropriation. The assumption of monitoring effectiveness also assures that recipients will be unable to pursue their own agenda with EU funds rather than the objectives accompanying the funding. Substitution of funding is therefore substitution of objectives.

Limiting the extent of financial substitution is the most direct implication of the "narrow" or financial definition of additionality, one subject of this report. Financial additionality is also closely related to the political issue of whether EU initiatives can be "additional" to the objectives of member states. As we have noted, member states have the option of substituting EU funding for their own but this also involves accepting the objectives accompanying EU funding. If EU and member state objectives are consistent, the impact of this substitution will be moot from the viewpoint of national governments while it may present a problem to the EU or other member states who expect that EU

\footnotetext{
${ }^{12}$ Further research on this mechanism would be very useful. One UK university that we interviewed had made increasing its attractiveness for EU funding a strategic goal in its research activities.
} 
funds will add to the level of effort in the funded area rather than substituting for national funding. With regard to other states, both political and economic issues may be at stake. ${ }^{13}$ This is the crux of the issue of additionality. It leads to two questions. First, are there means for the EU to measure and thereby adopt regulations to assure financial additionality (and the related additionality of effort)? Second, to what extent is substitution actually practised by member states?

Are there methods for assuring "additionality"? There is little possibility of guaranteeing that EU funds are strictly "additional" to member state funding that would have occurred in the absence of EU funding due to the problems of determining what base of national funding to use in evaluating additionality. It may, however, be possible to identify cases in which substitution is removing funds from areas funded by the EU and to infer from this that concerns about "additionality" are appropriate. For example, if national funding were to fall in concert with an increase in EU funds it is possible that substitution may be occurring. However, it is also possible that macroeconomic conditions within the member state are forcing fiscal stringency measures that require cuts in the base level of funding of a wide range of activities. It is conceivable that a standard might be set by which to assess the macroeconomic and fiscal pressures leading to such stringency and "reset" the base level for evaluating "additionality." Such a rule would be arbitrary in that there is no purely economic basis for allocating a total budget reduction among competing budgetary priorities. The political process of the member state may well determine uneven cuts to the sectors receiving EU funding even if this funding is not taken into account. This amounts to a basic problem in the evaluation of "additionality;" it is not possible objectively to determine what the base of national funding would have been in the absence of EU funding and thus to state definitively that the member state has substituted EU funds entirely for the funds that it would otherwise have spent in an area. In the absence of EU funding, the state may still have chosen to reduce funding by the same amount. Thus, for example, if the state reduces funding by the amount of the EU funds received, suggesting total substitution or no additionality--it is still possible that this would have occurred even without the EU funding, in which case the EU funds would be entirely "additional." An important exception would exist where the member state had explicitly adopted a policy of attribution in its budgetary process so that EU funds are included in allocation of funds, which, in turn, are based on "bottom up" definitions of roles and resources requirements.

13 For example, if these other states do not substitute away from R\&D, the member state that does may be said to be free riding on the "additional" efforts of those states that do not substitute EU for national expenditures. More generally, those states that do not substitute EU funds for national funds may fall somewhat behind in funding other programmes. These effects are likely to be relatively small given the size of the funds involved, but, nonetheless, noticeable. 
Approaches among member states within the EU to budget allocations differ. Some member states, like the United Kingdom, have adopted somewhat decentralized fiscal allocation mechanisms, where specific organisations like universities may receive funds from a variety of sources. In these circumstances, the contributions of funds from different sources must be taken into account to provide a check on whether the decentralized allocation mechanisms are consistent with overall fiscal objectives. In other member states, such as France, a more centralized budget making process makes it less necessary to monitor the funds received by specific organisations. As a result, reallocations involving substitution are more likely to be made in countries where public expenditure surveys are integrated into the fiscal control mechanism. A more specific examination of differences in member state practices in this area is needed to make conclusions about actual practices since the public record is widely dispersed and inconclusive as to what actual practices are at present.

It is, however, possible to conclude from a time series of member state and EU funding that substitution involving the absolute removal of funds is not occurring. In this case member state and EU funding both increase. This sort of examination is conducted for the aggregate funding of a number of Second and Third Framework Programmes in Section 3 of this report and concludes that "substitution" is not a pervasive or systematic problem among the member states for the RTD funds in these programmes under specific assumptions about the substitution practices of member states. Even in this case, though, it is not possible to state what the level of funding would have been in the absence of EU funding; perhaps it would have been even greater. Nonetheless, a demonstration that member state funding levels are increasing rather than decreasing in the area of activities funded by the EU should alleviate concerns on the part of the EU, or other member states, as to whether or not EU funding is stimulating additional effort.

Among the mechanisms that have been suggested for attempting to achieve additionality, one of the most commonly used is "matching funding." At first glance, such schemes would seem to assure that national allocations in the area where matching funds were offered would increase in proportion to EU funds granted conditional on the match. It is possible to imagine such a mechanism working if it is assumed that the activity selected is not one already being pursued by the national government, and if one assumes also that the national government is unwilling to reduce the funds it has chosen to allocate to other research efforts. If the first assumption is violated, then it is possible to "label" existing funding as the national contribution that should be matched by EU funds. If the second assumption is violated, then EU funds may serve to reduce funds available to other projects and EU grants have the unintended effect of changing national patterns of 
research funding. ${ }^{14}$ In short, the idea of matching does not escape the basic problem of determining the relevant base of national funding to use in evaluating additionality. Even if one assumes that EU grants are not anticipated by national governments prior to being required to meet a matching condition, it is possible for them to reduce the budgets of other activities (which, in any case, have fluctuating funding) to the institution, now or in the future, in order to recover such funds as the member state is required to offer to obtain EU matching grants.

In addition to an assessment of member state behaviour we will be concerned with whether substitution may be an issue affecting institutions within member states. In principle, the EU might wish to assure that research funding received at the level of the university or the business enterprise does not result in shifts of resources away from other activities undertaken by those entities. If such substitution does occur, then EU funding may produce unintended redirection of research priorities rather than additional efforts building upon existing research priorities. Among the institutions that might be effected by such substitutions are allocations of research funding across universities within a member state, allocations of research funding to departments or institutes within universities, and allocations of research funding within departments or institutes. All of these possibilities are considered in this report in Sections 4 and 5.

\footnotetext{
14 Unintended consequences play an important role in policy analysis and several such possibilities exist in the effort to assure that EU grants are not simply substitutes for national funds for research.
} 


\section{An Overview of Substitution Effects within the EU}

Recent efforts of the European Union to establish a targeted programme for improving industrial competitiveness through the mechanism of funded research officially began with the First Framework Programme (1984-1987). The Framework was set up with the goal of strengthening strategic areas of European competitiveness. The mechanisms selected for the Framework included a) funding the R\&D effort of private firms, research institutes, higher education institutes ${ }^{15}$ in the strategic areas, and b) attempting to allocate funding to stimulate the formation of research networks spanning organizational and national boundaries. With the Second Framework Programme (19871991) the Community decided to use the Framework as "..the basis and instrument of European research and technology policy....thus providing a clear structure for long term overall objectives"16. A comprehensive political strategy on technology, enjoying equal status with other key Community policy areas, was set. The Third Framework Programme (1990-1994) is characterized by the regrouping of activities around only three strategic areas with 15 separate programmes and by the reinforcement of the aim of convergence among the member states of the European Union. ${ }^{17}$ Lastly, the Fourth Framework Programme (1994-1998) pursues the guide lines of the previous one, putting more emphasis on the consistency between national and Community policy.

In the course of implementing the succession of Frameworks, European Union (EU) research and technological development policy has advanced in budgetary scope, as

15 The Community reimburses up to $50 \%$ of project actual costs to companies or institutes, and to universities and other higher education establishments it reimburses the $100 \%$ of additional costs.

16 See Commission of the European Communities, 1992, EC Research Funding. A guide for Applicants.

17 As is clearly stressed in Commission of European Communities 1992a, "...where projects are evenly matched in qualitative terms, preference will be given to projects involving participants from technologically less well developed regions." 
is illustrated in Table 1, and has developed a few key goals. In particular, the total budget of the Fourth Framework is more than three times that of the first in nominal value.

Table 1: The Framework Programmes.

\begin{tabular}{||l|c|c||}
\hline Programme & Duration & EU Contribution \\
\hline First Framework Programme & $1984-1987$ & 3.750 MECUs \\
\hline Second Framework Programme & $1987-1991$ & 5.396 MECUs \\
\hline Third Framework Programme & $1990-1994$ & 6.600 MECUs \\
\hline Fourth Framework Programme & $1994-1998$ & $12.300^{*}$ MECUs \\
\hline
\end{tabular}

Sources: Commission of the European Communities (1992a, 1993a, 1993b).

${ }^{*}$ It includes activities that were not encompassed in the other Frameworks.

The allocation of RTD funds under the Second and Third frameworks have been concentrated in ways that reflect member state differences in the level of research activities. Moreover, as is well known, the level of national funding for research in the smaller and lower income member states lags substantially behind that of the larger nations. As a result, the level of funds received by larger nations under the second and third frameworks offers opportunities for substitution while the amount received by the smaller and lower income countries practically limits the extent of substitution. ${ }^{18}$

From a broader perspective, the "principle of additionality" involves the extent to which EU funds foster efforts that would not be undertaken by member states acting independently. In this regard, one would first conclude that EU allocations that substantially increased national levels of effort were consistent with additionality. An examination of EU funding levels across member states indicates that research efforts of the smaller and lower income member states are substantially augmented through the receipt of EU funds. The size of EU RTD funding for the largest member states is less significant compared to member state allocations. It is therefore important to examine whether the funds received by larger countries reflect patterns of specialization where

\footnotetext{
18 See European Commission (1994a), Executive Summary, p. 42 which indicates that the amount received by three member states, Ireland, Greece and Portugal, is 10-35\% percent of their own government appropriation for civilian R\&D and that for Portugal and Greece, that EU funding for business enterprise research exceeds government funding. Hence, a significant amount of substitution in these countries would result in immediately apparent reductions in government financing of RTD. No such pattern exists.
} 
additionality would be assured because of relatively small national efforts in these areas. One possibility is that differences between EU and member state funding patterns are sufficiently small that patterns of specialization are similar at both member state and EU funding level. Such a pattern would be indicated by stability in a measure of concentration such as the Herfindahl index between EU and member state funding or between different frameworks at the aggregate level by member state. ${ }^{19}$

At an aggregate level the Herfindahl index of concentration at the level of member states is quite stable both between total budgeted RTD funding by member state and estimated EU funding and between the Second and Third frameworks. But, even with this observed stability, it might still be the case that national patterns of specialization do exist and that EU funding, at the programme level within the framework, would reflect a markedly different extent of concentration than they do at the aggregate level. When we examine the Herfindahl index at the level of programmes, there is only one major programme (among the 32 that we examined) for which the Herfindahl index on a member state basis markedly differs from the aggregate pattern of EU RTD funding, Human Genome. ${ }^{20}$ Thus, assuming that there are no other independent mechanisms at work (such as a political outcome that equalized allocations according to size of member state contribution to the overall budget), the indication is that at the level of the large programmes within the Second and Third Framework the largest member states had comparable capabilities in bidding on and receiving EU funds.

The extent of substitution of EU for member state funding of research efforts may be examined empirically using the committed funding of EU RTD programmes under the Second and Third Framework Programmes. We have utilized budgetary information on member state funding of $R \& D$ efforts in order to test the hypothesis that substitution may be a pervasive and systematic within the member states. This general proposition may be tested by adopting specific behavioural hypotheses about the relation between EU and national budgetary allocations. In our investigation we have examined two such hypotheses: 1) that changes in national budgetary allocations are negatively correlated with contemporaneous changes in EU funding and 2) that changes in national budgetary allocations are negatively correlated with changes in EU funding in the previous budgetary

19 The Herfindahl index is a comprehensive measure of concentration in the shares held by all the participants. It is computed by squaring the percentage share of each participant, and, by convention, this number is multiplied by 10,000 so that its ranges from an arbitrarily small number greater than zero to 10,000 . In the case of the EU where the number of participants in the years we are considering is 11 (we omit Luxembourg), the minimum value that can be achieved is $909.09(1 / 11 \wedge 2 * 10,000)$.

20 This programme is an area where one of the member states has internationally-recognized capabilities and is thus consistent with the idea of specialization leading to funding differences. 
cycle. We have examined these behavioral assumptions for 11 of the $12 \mathrm{EU}$ member states (Luxembourg is excluded due to its relatively small size) for budgetary allocations among the NABS chapters applied to the Second and Third Framework Programmes. From an econometric viewpoint, the two behavioral hypotheses yield a simple relationship between the level of member state and EU funding. If this relationship is systematically and pervasively negative we would conclude that substitution is widespread in the relation between EU and member state RTD funding. If this hypothesis is rejected, i.e. if there is a positive or indeterminant relationship between changes in member state and EU RTD funding we will conclude that substitution, if it exists, occurs through a more complex mechanism.

To test these two hypotheses we have used data on EU funding of RTD programmes under the Second and Third Frameworks. This data has been gathered for a subset of the Second and Third Framework programmes, ${ }^{21}$ and it is only for these programmes that we offer our conclusion. ${ }^{22}$ In particular, we have redistributed the original information, provided for the two Frameworks on an individual country basis, from funds by programme to funds by NABS category classification. To do this we have used the estimated share distribution by NABS chapter of funds for research and development in the general budget of the European Communities which gives the breakdown in NABS chapters of each programme. Then, with the indicated schedule of appropriation of the different programmes in the Second and Third Framework we have calculated the time series of the EU funding by NABS by country. ${ }^{23}$

We regressed the level of member state budgetary allocation by NABS chapter on the level of EU estimated allocations by NABS chapter for each year of available data. ${ }^{24}$ Six NABS chapters were separately analyzed: 1) Exploration and Exploitation of the

21 For the Third Framework Programme the information is up to the $31 / 12 / 1993$, then is about $85 \%$ of the budgeted RTD funds.

22 The data refer only to those parts of specific programmes implemented by shared-cost actions. No data was available for RACE, EUROTRA, COMMUNICATION TECHNOLOGIES and part of Agricultural and agroindustrial research programmes. For the list of the programmes taken into account see Annex (C).

\footnotetext{
${ }^{23}$ In the case of the Third Framework there is a discrepancy between the scheduled appropriation for the last year (1994) which is about 30\% of total allocations and the official figure (CEC, 1994a: 221) for the share of funds not yet committed which is about $15 \%$ of total allocations. To solve the problem and to use the same methodology used for the Second Framework, we calculated the year value on the base of the scheduled appropriation.

24 The NABS chapters reflect an assignment of RTD expenditure by socio-economic objectives. The use of NABS chapters is necessary in order to directly compare member state and EU funding as it is the only systematic basis for comparing EU and member state budgetary allocations in the RTD field.
} 
Earth, 3) Control and Care of the Environment, 4) Protection and Improvement of Human Health, 5) Production, Distribution and Rational Utilization of Energy, 6) Agricultural Production and Technology, and 7) Industrial Production and Technology. Table 2 shows the results of regressions by NABS chapter for the eleven member states examined for the years 1989-1993 under behavioural hypothesis one (that substitution occurs contemporaneously). The regressions reported in Table 2 are significant, both in terms of their explanation for variance and the coefficient on EC funds. (The constant term was also uniformly positive and significant; it is omitted for brevity.) In terms of behavioral assumption (1), the fact that the coefficient on EC funds is uniformly positive and significant leads us to reject the hypothesis that substitution is systematic or pervasive in contemporaneous funding level. We also tested two other sets of specifications. One accounted for fixed effects from the size of member states, time, and both factors. In these regressions, the coefficient on time is often significant and negative, indicating the general trend of a slowing rate of growth in national research expenditures in this time period due to macroeconomic influences. Dummy variables grouping countries by size were also often significant, a factor that led us to more closely examine country effects,

Table 2: $\quad$ Regression Results for Behavioural Assumption 1: Contemporaneous Substitution by Level of EU Funding. (Member State funding by NABS chapter is the dependent variable.)

\begin{tabular}{||l|l|l||}
\hline \hline NABS Chapter & Adjusted $\mathrm{R}^{2}$ & $\begin{array}{l}\text { EC funds } \\
\text { (t-statistics })\end{array}$ \\
\hline Exploration and exploitation of the earth & $.5964^{* *}$ & $15.266\left(5.410^{* *}\right)$ \\
\hline Control and care of the environment & $.5550^{* *}$ & $20.829\left(4.858^{* *}\right)$ \\
\hline $\begin{array}{l}\text { Protection and improvement of human } \\
\text { health }\end{array}$ & $.7132^{* *}$ & $41.468\left(7.409^{* *}\right)$ \\
\hline $\begin{array}{l}\text { Production, distribution and rational use } \\
\text { of energy }\end{array}$ & $.6728^{* *}$ & $19.514\left(6.621^{* *}\right)$ \\
\hline Agricultural production and technology & $.8289^{* *}$ & $28.375\left(10.790^{* *}\right)$ \\
\hline Industrial production and technology & $.8684^{* *}$ & $10.006(12.754 * *)$ \\
\hline
\end{tabular}

** significant at a $1 \%$ confidence level for F-test of regression or t-test of the coefficient.

the results of which are reported at the end of this section. Finally, we considered a refinement of the behavioural assumption, involving the possibility that member states would respond to changes in the level of EC funding rather than the level. This set of regressions performed less well; coefficients were uniformly insignificant for all NABS 
chapters. Thus, there is no evidence that member states are engaging, at a NABS chapter level, in widespread and pervasive substitution of EC funds for their own funding of RTD efforts in response to either the level or the change in the level of EC funding

Table 3 reports the results of regressions conducted under the second of our behavioural assumptions, that national budgetary allocations might be a response to the previous period changes in EU funding. The results reported in Table 3 lend support to the idea that member state funding is correlated with the prior year's level of EU funding. In particular, all of NABS chapters show a statistically significant relationship between the level of member state funding and the previous year's level of EU funding. All of these relationships are positive, i.e. the level of last years funding make a significant positive contribution to current year funding. This effect is similar, and perhaps slightly smaller, than the effect current year funding on national allocations to RTD by NABS chapter. As with our first behavioural assumption, we also ran one set of regressions accounting for time and country differences and one in which we considered the effect of country funding to changes in EU funding. Here too, we found some evidence of country differences, a significant and negative relationships accounting for time, and no evidence that substitution was occurring in response to changes in level. We conclude that there is a significant positive relationship between current levels of research funding and the lagged

Table 3: $\quad$ Regression Results for Behavioural Assumption 2:

Lagged Substitution by Level of EU Funding. (Member State funding by NABS chapter is the dependent variable.)

\begin{tabular}{||l|l|l||}
\hline NABS Chapter & Adjusted $\mathrm{R}^{2}$ & $\begin{array}{l}\text { EC funds in } \\
\text { Previous Year } \\
\text { (t-statistics) }\end{array}$ \\
\hline Exploration and exploitation of the earth & $.5172^{* *}$ & $14.339(3.917 * *)$ \\
\hline Control and care of the environment & $.4754^{* *}$ & $18.178\left(3.502^{* *}\right)$ \\
\hline $\begin{array}{l}\text { Protection and improvement of human } \\
\text { health }\end{array}$ & $.6379 * *$ & $40.689(5.369 * *)$ \\
\hline $\begin{array}{l}\text { Production, distribution and rational use } \\
\text { of energy }\end{array}$ & $.6461^{* *}$ & $17.773(5.487 * *)$ \\
\hline Agricultural production and technology & $.7739 * *$ & $27.058\left(7.921^{* *}\right)$ \\
\hline Industrial production and technology & $.8463^{* *}$ & $9.916\left(10.298^{* *}\right)$ \\
\hline
\end{tabular}

** significant at a $1 \%$ confidence level for F-test of regression or t-test of the coefficient. 
value of EU funding, and that this relationship is uniformly inconsistent with the hypothesis of substitution. Hence, we again reject the hypothesis that member states are engaging, at a NABS chapter level, in systematic and pervasive substitution of EC funds for their own funding of RTD efforts in response to either to the past year's level or the change in that level of EC funding.

Because alternative specifications including the effects of member state size (by size classification) indicated the possibility of fixed effects at the level of the member state, we adopted two approaches. First, despite a small number of observations, we regressed member state on EC funding by NABS chapter for the 5 years of available data. In the resulting regressions (66 in number, 6 NABS chapter by 11 member states) 22 of the coefficients were statistically significant at least at the $10 \%$ level. Of these 22 , three were negative. That is for three country-NABS chapter pairs, the estimated coefficient on EU funding indicated the possibility of an additionality problem. Two countries are involved, both are smaller member states and we conclude that this effect was either anomalous or of minor significance to our general conclusion.

To further examine the possibility of country effects, we pooled EU and national funding by NABS chapter by country. This made it possible to examine, at the member state level, what response had occurred to the level of EU funding. These regressions make it possible to test the hypothesis that a specific country's choices reflect a reduction of national funding in response to an increase in EC funding of RTD programmes.

The results of these regressions may be examined in relation to the calculated yaxis intercept for a country and the coefficient on EC funds. A negative coefficient on EC funds would indicate the presence of substitution for that country. Figure 1 charts the outcome of this regression. The shaded area at the bottom of the figure represents the territory in which substitution problems may be present. As indicated by the arrow, only one country is near this level. In fact, its estimated coefficient is statistically insignificant. This particular country is one of the smaller EU countries, both in own expenditure and in receipts of EU funding relative to others. All the other countries have coefficients that indicate substantial additions of national funding in response to EU funding. Thus, in aggregate terms, these countries cannot be making major substitutions of EU funding for national funds. Alternative specifications of this model incorporating lagged levels of EU funding and both contemporaneous and lagged levels of EU funding yield the same outcome, an absence of substitution effect. 
Figure 1. Member State Financing as Explained by Contemporaneous Levels of EU Funding

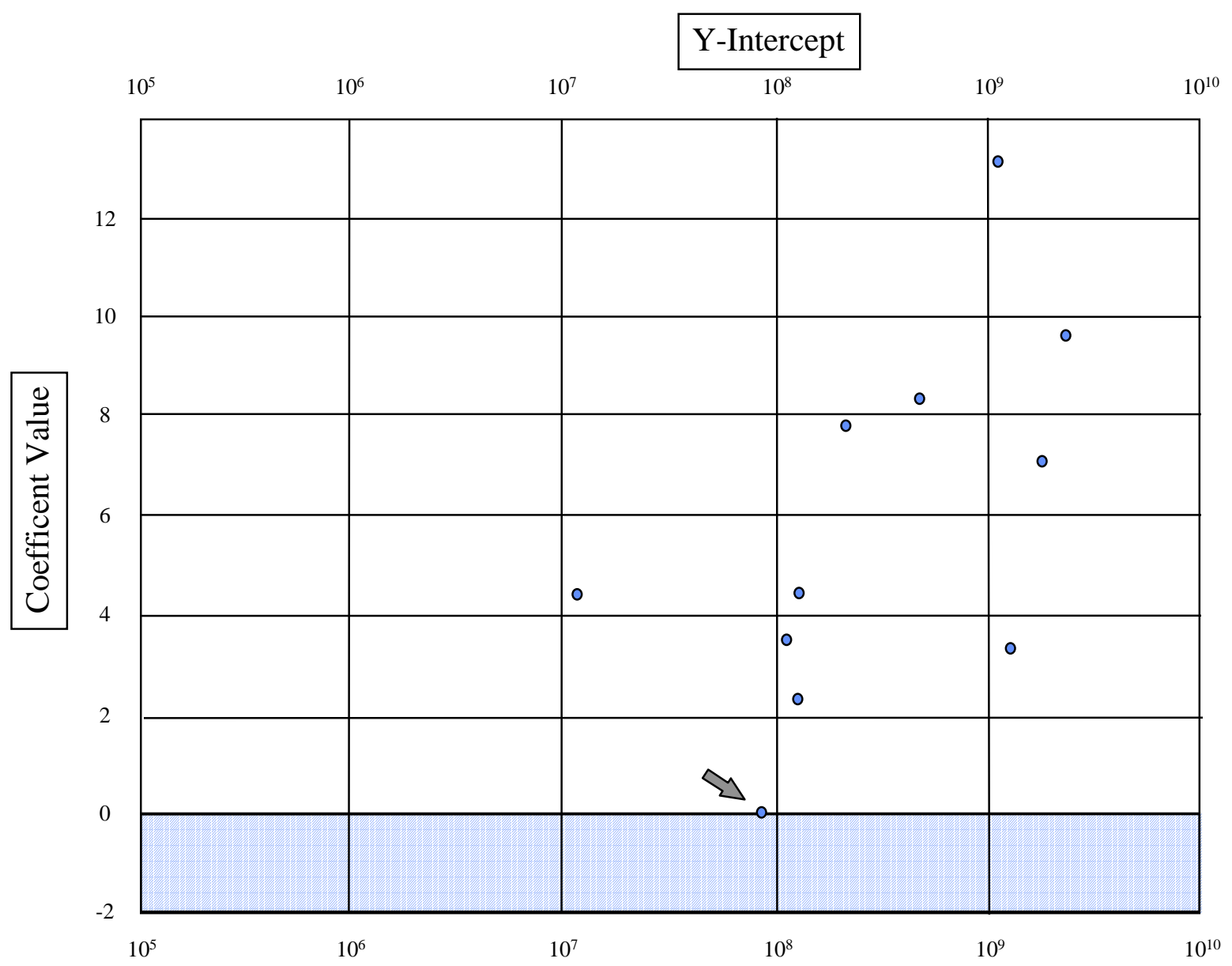

Note: The Intercept and Coefficient Values for a Pooled Sample of NABS Chapter Funding across Chapters and Years by Country ( $\mathrm{n}=30$, five years by six NABS chapter) Estimated Relationship : Member State RTD funding (year, NABS chapter) $=$ constant + coefficient * EU RTD funding (year, NABS chapter)

Constant terms and coefficients are all significant at the $1 \%$ level except for the country designated by the arrow where the coefficient is insignificant.

In summary, at an aggregate level we have found that the distribution of EU RTD investments among member states is similarly concentrated as member state RTD investments as measured by the Herfindahl index. For member states with the smallest levels of investment, EU funding is large enough that substitution would be quite visible if it occurred in any systematic way. For larger recipients of EU RTD funding, which are 
also larger investors in RTD, the opportunities for substitution are more substantial. A similar relationship applies at the level of programme expenditure, with one programme being an exception, Human Genome, i.e. having a marked difference between EU and national funding shares as measured by the Herfindahl index of concentration.

We have tested two behavioural hypotheses about the nature of possible substitution relationships, based upon the relation of national funding to the level of EU funding at the Chapter level of the NABS code for social purposes of RTD activity. The first behavioural hypothesis is that substitution occurs contemporaneously, i.e. the level of member state RTD funding would be negatively correlated with the level of EU RTD funding. Regressions on this relationship by NABS chapter indicate no such relationship, but on the contrary, a strong positive relationship EU and national funding within each of the NABS chapters. We therefore reject the first behavioural hypothesis that substitution is occurring contemporaneously. In our second behavioural hypothesis, substitution occurs in response to the past years level of EU funding. The set of regressions based on this behavioural hypothesis are also statistically significant for all also six NABS Chapter codes and indicate a strong, statistically significant, positive relationship between EU and national funding. In examining country effects more closely we also find a strong and positive relationship between EU and country funding for all but one country which is one of the smaller countries in the EU in terms of both EU and national funding. Alternative specifications of each of the above relationships lead to very similar results, with time, in particular, providing further evidence of a general slowdown in the rate of growth of RTD funding at the national level which continues to be positively related (and statistically significant) to EU funding.

Our overall conclusion is that no systematic or pervasive substitution relationship can be detected from available data at the NABS chapter level of RTD funding on the basis of relatively simple behavioural hypotheses about the response of member states to changes in EU funding. 


\section{University participation in Community Programmes}

The European Commission classifies the institutions that participate in the Framework Programmes in one of five categories: Big Companies (BIG), Small and Medium Enterprises (SME), Public or Private Research Centres (REC), Higher Education Institutions (HEI) and Others. ${ }^{25}$ In Table 4 we have shown the distribution of the five types of institutions in terms of (a) number of participations and (b) funding for shared cost actions for the Second and Third Framework Programme. ${ }^{26}$ Two main observations emerge from this table. First, BIG have suffered a decrease between the Second and Third Framework both in the number of participations and in their funding. Most of the 11 percentage point cut in BIGs' funding was redistributed to "research institutions," research centres and higher education, with the result that the latter institutions' funding approached 50\% in the Third Framework Programme, up from 40\% during the Second Framework. Second, in both periods "research institutions" have a markedly higher share of participations than their share of funds. This means that funds are more thinly spread, on average, across participating units in the research centres and higher education community than among participating businesses. For HEI, the difference in share of participation and funding shrank between the Second and Third Framework Programmes, but still remained about ten percentage points.

Nevertheless, HEI are continuing to play an important role in the EU's research and technological development policy. On the one hand, they are supplying basic knowledge needed by business enterprises, and, on the other hand, they are benefitting from gaining access to complementary expertise and instrumentation in BIGs' R\&D laboratories. Moreover, for HEI, participation in a Framework project means not only

\footnotetext{
25 Each participant in a contract has to classify his institution in relation to the previous five categories. We prefer to use Higher Education Institutions (HEI) instead of the term Higher Education Establishments (HEE), official use by the European Commission, due to its more commune utilization.

26 For the Third Framework Programme the figure refers to circa the $85 \%$ of the contracts.
} 
access to EU funding, but also the opportunity to interact with industry in the formation of new, high quality research networks. This is extremely important, especially for those countries with lower scientific and technological resources, because it enables such

Table 4: Distribution of participations (a) and funding (b), by organizational type.

\begin{tabular}{||l|c|c|c|c||}
\hline Organization Ty pe & $\begin{array}{l}\mathbf{a}(\%) \\
2^{\text {nd }} \mathrm{F} .\end{array}$ & $\begin{array}{l}\mathbf{a}(\%) \\
3^{\text {rd }} \mathrm{F} .\end{array}$ & $\begin{array}{l}\mathbf{b}(\%) \\
2^{\text {nd }} \mathrm{F} .\end{array}$ & $\begin{array}{c}\text { b }(\%) \\
3^{\text {rd }} \mathrm{F} .\end{array}$ \\
\hline $\boldsymbol{B I G}$ & & & & \\
\hline $\boldsymbol{S M E}$ & 21.9 & 17.2 & 41.1 & 30.0 \\
\hline $\boldsymbol{R E C}$ & 18.1 & 17.6 & 18.7 & 21.1 \\
\hline $\boldsymbol{H E I}$ & 29.5 & 30.3 & 20.8 & 23.2 \\
\hline Other & 29.2 & 31.5 & 18.9 & 21.8 \\
\hline
\end{tabular}

Source: Commission of the European Communities (1994a) .

countries to overcome the constraints imposed by the small size of their research community. In Table 5 we show the evolution of collaborative links by organization type for HEI.

In moving from the Second to the Third Framework programmes, the number of HEI links with other HEI and with research centres, both increased. Nonetheless, $29 \%$ of the links are still with either BIG, SME, or other industrial partners. The number of links are affected by the increasing numbers of HEI and REC participating in the framework. Despite this increase, university-industry collaborations remain important in the Third Framework. Indeed, when we look at the specifics of network formation, it is often the case that when there is cooperation between "research institutions" and industry, a larger number of universities/research centres are linked to a single firm. Thus, in the simple count of links, BIG and SME are contributing a smaller share than other organisations, but these organizations links often produce a multi-directional transfer of knowledge.

Moreover, when we consider the total number of collaborative links, we can identify three relevant groups. First, the industrial group --i.e. collaborative links BIG-BIG, SME-SME and BIG-SME-- with about $30 \%$ and $19 \%$ of the links in the Second and Third Frameworks respectively. Second, the research group --i.e. collaborative links HEI-HEI, REC-REC and HEI-REC-- which have not only the largest but also an increasing share of 
links, circa $39 \%$ and $50 \%$. Third, the hybrid group --i.e. collaborative links across the institutions of the two previous groups-- with about $30 \%$ and $27 \%$ of the links respectively. The cooperation between "research institutions" and industry, characteristic of the hybrid group, although decreasing is nonetheless significant part of the picture.

Finally, to confirm the intuition that the cooperation between industry and "research institutions" is still extremely important, we looked at the EU contractual funding across different programmes for HEI. On the one hand, when we consider the share distribution for each programme by type of participant we identify a group of programmes in which HEI have about $50 \%$ of the funds. They are Step/Epoch, Bridge and Science And Technology For Development, ${ }^{27}$ in the Second Framework, and Environment, Marine Science And Technology, Biotechnology and Life Sciences And Technologies For Developing Countries, in the Third Framework. On the other hand, when we focus on the share distribution for each type of participant by programme the previous group of university-oriented programmes loses importance. The two industriallyoriented programmes, Esprit and Brite-Euram, and their continuations under the Third Framework, are always the most important sources of HEI funding. ${ }^{28}$ This result shows that the research university continue to play a major role in cooperation with industry.

Table 5: Collaborative links involving HEI and REC, by Framework.

\begin{tabular}{||l|l|l|l|l||}
\hline \hline Organization type & \multicolumn{2}{|c||}{$\mathbf{2}^{\text {nd }}$ Framework } & \multicolumn{2}{|c||}{$3^{\text {rd }}$ Framework } \\
\hline HEI & HEI & REC & HEI & REC \\
\hline REC & $25.6 \%$ & $36.0 \%$ & $29.8 \%$ & $42.4 \%$ \\
\hline BIG & $36.7 \%$ & $28.6 \%$ & $40.6 \%$ & $28.5 \%$ \\
\hline SME & $19.6 \%$ & $18.5 \%$ & $14.8 \%$ & $14.1 \%$ \\
\hline Other & $16.6 \%$ & $15.4 \%$ & $12.1 \%$ & $12.1 \%$ \\
\hline \hline
\end{tabular}

Source: Elaboration of EU data, 1994.

27 We do not take into account the programmes under the chapter Improvements To European Scientific And Technological Cooperation due to their specific character.

28 Only Environment, among the programmes of the previous group, receive in absolute terms a relevant share of funds $(16 \%)$. 


\subsection{BRITE-EURAM and the United Kingdom case}

Keeping in mind that the goal of our present inquiry is a better understanding of the meaning of "additionality", we chose to focus our empirical analysis first on a specific EU programme, and then on the implementation of that programme in a specific country. We believe that only with a detailed analysis is it possible to highlight and understand the micro-mechanisms at work in the "implementation" of European science and technology policy. Our specific choice for this report was influenced by the prior availability of data and experience on the institutional details of the EU BRITE-EURAM I and Industrial and Materials Technologies (BRITE-EURAM II) research programmes. We first examine some aggregate indicators related to that programme and then proceed to analyze its implementation in the case of the UK. A broader and larger study would take into account multiple programmes and multiple countries.

The following analysis focuses on the contracts signed in the period 1st November 1989, 1st March 1994 in the EU BRITE-EURAM I and BRITE-EURAM II (henceforth in general B-E) programmes. B-E represents a particularly suitable programme for our purpose for the following reasons. First, its technological and sectoral foci represent a heterogeneous set of participants (CEC,1992b: p.41; CEC,1993c: p.10). Second, the sectoral orientation involves not only applied and development work, but also more basic research with industrial applicability. These features mean that REC and HEI participation can be studied with a view to discerning possible impacts of EU policy on the balance between applied and basic research with particular classes of organisation. Third, if we consider both the number of participation and the funding level for shared cost actions, B$\mathrm{E}$ is the second most important programme throughout this period.

The database we are using ${ }^{29}$ takes into account about $90 \%$ of the contracts (of those involving shared cost actions) signed during the Second Framework, and $85 \%$ of those signed during the Third Framework. ${ }^{30} \quad$ As shown in Table 6, 7, 8 we have a population of 3,440 participations distributed among 637 contracts, with 350 contracts in the Second Framework and 323 in the Third. The type of cost, MAR or ECO, identifies the participants that receive up to $100 \%$ of the additional cost (MAR, limited to HEI), and the other category of participants, to whom the Community reimburses up to $50 \%$ of the project costs (ECO). Comparing these figures with the total (Table 4) we note that the BE programmes are characterized by a lower level of HEI participation than the total of all

\footnotetext{
${ }^{29}$ For the description of the database and for a first analysis of the network formation see Garcia and Geuna, 1994.

30 The Third Framework will last up to the end of 1994, then the $85 \%$ represent an estimate of the contracts signed up to 1st March 1994.
} 
Framework programmes. Moreover, EU funding in all programmes for HEI increases from 19 to $22 \%$ of the total in moving from the Second to the Third Framework while the funding share of HEI in the B-E programmes falls from 27 to $23 \%$. Nonetheless, the share of HEI funding in $B-E$ remains above the HEI's share in the total of all EU programs. Furthermore, there is a smaller gap between the share of participation by number, (Table 6) and by funding (Table 7) in B-E relative to overall EU funding of research programmes (Table 4). Therefore, even if HEI have lost share, they remained strong players in the B-E programme.

Table 8 indicates that industry plays an important role in establishing the research efforts under BRITE-EURAM with a dominant role as the "main investigator" in both Frameworks.

Table 6: Participations in the two frameworks, break down by type of cost.

\begin{tabular}{||l|c|c|c||}
\hline Cost Type & $2^{\text {nd }}$ Framework & $3^{\text {rd }}$ Framework & Total \\
\hline ECO & $1302-73.2 \%$ & $1221-73.5 \%$ & $2523-73.3 \%$ \\
\hline MAR & $476-26.8 \%$ & $441-26.5 \%$ & $916-26.7 \%$ \\
\hline TOTAL & 1778 & 1662 & 3440 \\
\hline
\end{tabular}

Source: MERIT data, 1994.

Table 7: EU contribution in the two frameworks, break down by type of cost. (in million ECU)

\begin{tabular}{||l|ll|ll|ll||}
\hline Cost Type & \multicolumn{2}{|c|}{$\mathbf{2}^{\text {nd }}$ Framework } & \multicolumn{2}{|c||}{$\mathbf{3}^{\text {rd }}$ Framework } & \multicolumn{2}{|c||}{ Total } \\
\hline ECO & 275.4 & $73 \%$ & 292.7 & $77 \%$ & 568.1 & $74 \%$ \\
\hline MAR & 101.4 & $27 \%$ & 88.6 & $23 \%$ & 189.0 & $26 \%$ \\
\hline TOTAL & 376.8 & 380.3 & 757.1 & \\
\hline
\end{tabular}

Source: MERIT data, 1994. 
Table 8: Main investigators, break down by type of cost.

\begin{tabular}{|c|c|c|c|}
\hline Cost Type & $2^{\text {nd }}$ Framework & $3^{\text {rd }}$ Framework & Total \\
\hline ECO & $278 \quad 79.4 \%$ & $26381.4 \%$ & $54180.4 \%$ \\
\hline MAR & $72 \quad 20.6 \%$ & $60 \quad 18.6 \%$ & $132 \quad 19.6 \%$ \\
\hline TOTAL & 350 & 323 & 673 \\
\hline
\end{tabular}

Source: MERIT data, 1994.

The next step in narrowing the focus of our analysis and improving its level of detail, is to focus specifically on the case of the United Kingdom. ${ }^{31}$ The UK was selected for two main reasons. First, after the Education Act (1988) the university funding system in United Kingdom has undergone profound modifications. Due to these changes, EU funding is playing a larger and more important role, both directly, through an increase of the EU share of total HEI research funding, and indirectly, through a series of cumulative and self-reinforcing mechanisms explained in more detail below. Second, the new UK "market oriented" approach may serve as a model for emulation by other, continental systems, raising the importance of understanding its development and consequences.

Table 9 shows the participations of UK institutions in the B-E programmes. The share of HEI participations, almost equal in the two Frameworks $(35.7 \%-35.8 \%)$, is about 9 points higher than the aggregate value. ${ }^{32}$ The B-E programme has focused on a subset of the 133 institutions of higher education in the UK (International Handbook of Universities, 1994). Only 49 different institutions account for the 201 participations by UK HEI. ${ }^{33}$ Moreover, only four new institutions appear on the roster of HEI supported by the Third Framework, while fourteen institutions that were in the Second Framework did not participate in the Third Framework, leaving 31 institutions that took part in both Framework Programmes. Of the 49 different HEI's participating in either Framework, 40 are "old" universities. In other words, ex-polytechnics and other higher education

\footnotetext{
31 For a broad analysis of the UK situation see the report "The impact of European Community Policies for Research and Technological development Upon Science and Technology in the United Kingdom", L. Georghiou et al., 1993.

32 See Table 6 the share of MAR.

33 At this level we focus our attention on the university, therefore different departments in the same institution are considered equal. This is due to our theoretical focus. We want to evaluate the effect of EU funds at the level of the institution.
} 
institutions rarely succeed in getting the funds from the EU. ${ }^{34}$ Finally, when we consider the University of London rather than the different colleges comprising the University of London, there are 36 old university participants in at least one of the B-E programmes, or $68 \%$ of the 53 "old" UK universities.

Table 9: $\quad$ Participations of UK institutions.

\begin{tabular}{||l|l|l|l||}
\hline & $\mathbf{2}^{\text {nd }}$ Framework & $\mathbf{3}^{\text {rd }}$ Framework & Total \\
\hline Tot. Participations & 311 & 251 & 562 \\
\hline HEI Participations & $111-35.7 \%$ & $90-35.8 \%$ & $201-35.7 \%$ \\
\hline HEI Institutions & 45 & 35 & 49 \\
\hline
\end{tabular}

Source: MERIT data, 1994.

This analysis raises some concerns about whether the effect of EU funds might be to further concentrate research funding within the United Kingdom. As we will see, however, there are several important subtleties in this story that call for a more nuanced interpretation of the impact of EU funding on UK institutions of higher education.

34 An intriguing question is to understand if these institutions do not have the competence/quality for applying to the EU or if they "strategically" decide not to apply. 


\section{UK universities, funding mechanisms and EU impact.}

As noted earlier, one of the reasons for selecting the UK was the marked changes in higher education financing that have occurred there in recent years. These changes were the result of government policies that began, in 1980, with the decision to charge fees to foreign students to cover the full costs of their courses. Then, throughout the 80's, university, polytechnic, and college budgets were restructured in ways that put new pressures (and incentives) on these institutions. A major instrument of reform was a reduction in block grants to HEI which then were offset, less-then-proportionately, by increases in funds from other government sources. The actions were undertaken, on the one hand, to stimulate a process of financial restructuring aimed to reduce costs and, on the other hand, to provide incentives--through mechanisms like quality assessment and technology foresight--by which it was hoped that better direction of HEI research effort would result.

The turning point in the process of change of the funding system was, however, the Education Reform Act 1988. This Act created two new funding agencies, the Universities Funding Council (UFC) and the Polytechnics and Colleges Funding Council (PCFC), but most importantly it modified the 'logic' of higher education funding. The two agencies were created to act as buyers of academic services. The role of universities, polytechnics and colleges was suddenly transformed, from the one of public institutions subsidized by the state into that of private suppliers of specific services --i.e. teaching and research. This change implied the creation of a new market for HEI services. HEI had to learn the new rules of the game, such as bidding for students and interacting with other potential buyers of their services --e.g. industry, or the European Commission.

Furthermore they had to adapt their management structure and allocation of funds to the new external situation. ${ }^{35}$

The latest step of this revolution has been the merging of UFC and PCFC into a single Higher Education Funding Council (HEFC) with separate agencies for England,

\footnotetext{
${ }^{35}$ For an exhaustive analysis of these changes see G. Williams (1992a).
} 
Scotland and Wales in 1993. In addition, 39 Polytechnics and Colleges have been granted university status. This new situation is also the result of the White Paper of May 1991 Higher Education. A New Framework. The report drew the lines for the new structure of the higher education sector in UK. Of particular relevance for the funding system are the following. Firstly, it has favoured competition for research funds among all the HEI institutions, now all sharing a common identity as universities. Secondly, it endorsed and reinforced the dual support approach. Universities should receive public funds for research from both the national HEFC and from the Research Councils ${ }^{36}$ for specific projects. Thirdly, together with competition among institutions and the dual system, selectivity on the basis of assessment of research quality and the subdivision of the block grant in teaching and research are the principles that inform the new structure for public funding.

Finally, as a demonstration of Government 's concern for the science and technology situation, in May 1993 a new White Paper (the "Waldegrave Report") on science and technology, Realising our Potential - A Strategy for Science, Engineering and Technology, was published. More than being another proposal for further changes, it offered an evaluation of what had happened in the preceding years, and a re-thinking of the system of science, engineering and technology in general. Central to the Waldegrave Report is an examination of the research councils' operation, including the prospects for the three new councils. From 1994 there will be eight active research councils, namely the Natural Environment Research Council (NERC), the Medical Research Council (MRC), the Economic and Social Research Council (ESRC), the Agricultural and Food Research Council (AFRC), the Science and Engineering Research Council (SERC), as well as the new Engineering and Physical Science Research Council (EPSRC), the Biotechnology and Biological Sciences Research Council (BBSRC), and the Particle Physics and Astronomy Research Council (PPARC). The Office of Science and Technology has the responsibility for all the Research Councils and also for the LINK programme, "a cross-Government initiative which aims to bridge the gap between the science and engineering base and industry for the benefit of the United Kingdom economy" (White Paper, 1993, p. 35).

Moreover, of extreme importance in the context of the present inquiry is the way in which the UK government considers the costs of Community research. "Like other Member States, the United Kingdom must strike a balance between the funds it devotes to

\footnotetext{
36 Overheads have been increased to $40 \%$ so that the Research Council "will become responsible for meeting all the costs of their projects, except for academic salaries and premises, which will continue to be met from institutions' general funds" (White Paper, 1991, p.17).
} 
Community and domestic programmes. The system of attributing the cost of Community expenditure to Departments ... has given Departments a clear incentive to seek value for money from the Community programmes." (White Paper, 1993, p. 49). The clear stress which the Waldegrave Report thus placed on the process of attribution and then on the consequent, even if not reported, process of substitution was relaxed a few lines later, however, by the statement that the government is annually entitled to "judge the best practicable balance between domestic and Community programmes" on a year-to-year basis. $^{37}$

\subsection{The aggregate situation}

Due to the relevance of the Education Reform Act and to the fact that the EU data are only available from 1989-1990, we shall focus our analysis on the period between 1989-90 and 1992-93. Furthermore, we decided to take into account only the "old" universities because of their distinct research orientation. Indeed, polytechnics and colleges receive much less research funding; in 1989-90 the levels were $£$ 1,620 million for the old universities and $£ 70$ million for polytechnics and colleges (White Paper 1991, pp. 16). ${ }^{38}$ Since we will analyze the interaction between EU research funds and national funding for research, our focus "old" universities omits a relatively small portion of the economic story of research in UK higher education institutions.

The Universities' Statistical Record provides an annual report on university funding. All the old universities are covered in this survey. The university funding (income) is broken down in detail by income source. At the most aggregate level the break-down is between general and specific incomes. The former represent the incomes attributed to teaching and to the part of research not covered by specific sources. The main part of it is due to HEFC grant (Exchequer Grants) and to tuition fees (Fees). The latter consist of the funds gathered by academic departments or academic services for the supply of a specific services to outside parties. Among these services, research grants and contracts are the most important item and the following are the largest buyers of university

37 The Waldegrave Report is somewhat unclear on what the term "value for money" might mean. It could mean only that, as the UK government would have to fund salaries and pay for facilities from the grant, they should only accept grants that were believed most beneficial (or professionally rewarding). On the other hand, it could imply that the institutions would be made to give up UK government funds for salaries and facilities rental that such grants utilized and would thereby prevent the organisation or institution from expanding its research activities on the basis of EU funding.

38 However, with the new system of funding ex-polytechnics and colleges are starting to compete more and more for Research Council funding, and they are therefore becoming more involved in research. 
research: Research Council, Government Bodies, European Commission, UK - based Charitable Bodies and UK Industry.

In Table 10 we have shown the evolution of the relative share of the sources of funds in which we are interested. The most striking trend is the decrease of more then 15 points of the Exchequer Grants' share in university funding. This is the result of both the policy of funding a higher share of university research directly through specified projects, and the decision to link part of teaching money to the number of students, via the increase of fees. $^{39}$ In addition, the share of Fees grew by 11.5 points, reaching the value of $25.3 \%$. There are two main reasons for this increase. First, the Government sought an incentive for enlarging the number of students admitted to the university. Thus, to spur universities to accept more students they increased the money given to the institution for each admitted student. Second, this policy was successful in the sense that the number of students admitted to higher education markedly increased during the period, raising the total funds paid through this source. The EU share of funding, although very low, more or less doubled over the period. Moreover, taking into account that the EU source is part of specific incomes, not only does its relevance increase, but about $50 \%$ of the growth of the specific component is the result of the increase of EU funding. Finally, the Research Council's share of funds, after a slight decrease over two years, increased in the last year. This is mainly due to the new regulation that states that from 1992-93 the Research Council "will become responsible for meeting all the costs of the projects, except for academic salaries and premises, which will continue to be met from institutions' general funds" (White Paper, 1991, p.17). ${ }^{40}$ The result is that part of the costs associated with the conduct of research facilities, like libraries, were then paid for by the research councils.

In Table 11 we have shown the annual growth rate of the various sources of funds expressed in constant prices of 1986. Focusing only on the total figure for the United Kingdom we can go a bit deeper than the analysis previously presented. First, the decrease in the real value of Exchequer Grants, which started during the 80's is moderating. Indeed, in 1992-93 there was a nominal (without taking into account inflation) increase. Second, the Research Council component after two years of decline realized an increase of $26.5 \%$. However, when we compute the real value of the flow of money from the Funding Council (see note 20) we obtain a negative growth of 2.3 points.

\footnotetext{
${ }^{39}$ The share of self-supporting home fees, payed by UK residents or by residents abroad who are entitled by special circumstances to pay home fees (EC students), ranged from $2 \%$ to $4 \%$ in these four years. In short, fees are principally paid by the UK Government.

${ }^{40}$ In particular, research grants and contracts income from the Research Council increased from £288 million to $£ 382$ million, due mainly to the transfer of $£ 87$ million from the Funding Council to the Science Vote.
} 
Table 10: Relative share of funds.

\begin{tabular}{|c|c|l|l|l|l|l||}
\hline \hline Year & EC & $\begin{array}{l}\text { Other } \\
\text { Specific }\end{array}$ & $\begin{array}{l}\text { Research } \\
\text { Councils }\end{array}$ & $\begin{array}{c}\text { Govern. } \\
\text { Bodies }\end{array}$ & $\begin{array}{l}\text { Exch. } \\
\text { Grants }\end{array}$ & Fees \\
\hline $\mathbf{1 9 8 9 - 9 0}$ & $1.1 \%$ & $22.0 \%$ & $6.5 \%$ & $3.0 \%$ & $48.4 \%$ & $13.8 \%$ \\
\hline $\mathbf{1 9 9 0 - 9 1}$ & $1.3 \%$ & $22.9 \%$ & $6.4 \%$ & $3.3 \%$ & $39.8 \%$ & $20.7 \%$ \\
\hline $\mathbf{1 9 9 1 - 9 2}$ & $1.6 \%$ & $22.4 \%$ & $6.0 \%$ & $3.1 \%$ & $35.5 \%$ & $25.0 \%$ \\
\hline $\mathbf{1 9 9 2 - 9 3}$ & $1.9 \%$ & $23.2 \%$ & $7.1 \%$ & $3.1 \%$ & $33.3 \%$ & $25.3 \%$ \\
\hline \hline
\end{tabular}

Source: MERIT elaboration of Universities' Statistical Record data.

Therefore, it appears that even over the recent past the two most important government sources of funds have shown negative trends. Only in the last year, after a strong policy action, does it seem possible to identify the impact of the government strategy oriented towards an increase of specific incomes ${ }^{41}$ and not simply directed at cutting both general and specific incomes. Third, EU funding receipts have risen throughout the period, whereas the positive growth of university income from Fees has been slowing down. Fourth, and finally, after more or less no changes in real terms during 1989-90/1990-91, Total Recurrent incomes has shown a positive growth rate during the two following periods.

For three years, from 1990-91 to 1992-93, there are statistics for all the old universities. In total there are 74 different universities, $52^{42}$ if we consider University of London as a single institution rather than counting its 23 component institutions. From an analysis of the distribution of funds among these universities, focusing in particular on Research Council (RC) and the EU component, the following observation can be drawn ${ }^{43}$. First, the distributions of both components are positively skewed with a higher coefficient of skewness for the RC. This means that they are both characterized by a very small number of universities that receive a lot of money and a very large number of institutions that secure very limited funds. However, this is less evident for the EU source, which is to say that the EU component is more evenly distributed across institutions. Second, the

41 To favour specific incomes is a way to create incentives for the university in the model of competitive market for university research that the government is perusing.

42 The Universities' Statistical Record reports 53 different institutions counting the University of London as one. However, we decided to exclude from this analysis the University Central Registry.

43 See the statistical annex for all the figures (Annex A). 


\begin{tabular}{|c|c|c|c|c|c|c|c|c|c|c|c|c|c|c|c|}
\hline 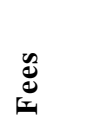 & $\begin{array}{l}\stackrel{8}{0} \\
\stackrel{0}{0} \\
\dot{q}\end{array}$ & $\begin{array}{l}\stackrel{0}{0} \\
\stackrel{\square}{\dot{f}} \\
\vec{f}\end{array}$ & 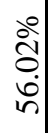 & $\begin{array}{l}\stackrel{8}{\grave{n}} \\
\stackrel{n}{n}\end{array}$ & 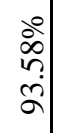 & $\begin{array}{l}\stackrel{8}{0} \\
\stackrel{0}{+} \\
\dot{d}\end{array}$ & $\begin{array}{l}\frac{0}{7} \\
\vec{i} \\
\dot{\lambda}\end{array}$ & 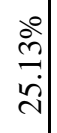 & 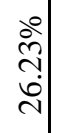 & $\begin{array}{l}8 \\
8 \\
\vdots \\
\grave{\lambda}\end{array}$ & 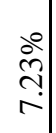 & $\begin{array}{l}\stackrel{0}{0} \\
\stackrel{n}{?} \\
r\end{array}$ & $\begin{array}{c}0 \\
8 \\
0 \\
\infty\end{array}$ & $\begin{array}{l}80 \\
0 \\
0 \\
0\end{array}$ & $\begin{array}{l}\stackrel{0}{0} \\
6 \\
i \\
\end{array}$ \\
\hline 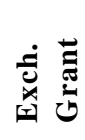 & $\begin{array}{l}00 \\
0 \\
0 \\
\vdots \\
1\end{array}$ & $\begin{array}{c}0 \\
0 \\
0 \\
\vdots \\
1\end{array}$ & $\begin{array}{l}\stackrel{0}{0} \\
\stackrel{\overbrace{}}{1} \\
\stackrel{\Upsilon}{1}\end{array}$ & $\begin{array}{l}0 \\
n \\
n \\
\\
1\end{array}$ & $\begin{array}{l}0 \\
0 \\
+ \\
\vdots \\
0 \\
1\end{array}$ & 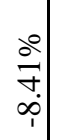 & 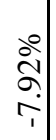 & 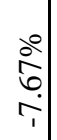 & $\begin{array}{l}\stackrel{0}{0} \\
\infty \\
\vdots \\
i\end{array}$ & $\begin{array}{l}00 \\
\frac{0}{n} \\
\frac{n}{1}\end{array}$ & $\begin{array}{l}00 \\
\vdots \\
0 \\
1 \\
1\end{array}$ & $\begin{array}{l}0 \\
0 \\
0 \\
0 \\
1\end{array}$ & $\begin{array}{c}0 \\
0 \\
0 \\
0 \\
i\end{array}$ & $\frac{\circ}{a}$ & $\begin{array}{l}0 \\
2 \\
0 \\
0 \\
-1\end{array}$ \\
\hline ن & $\begin{array}{l}80 \\
0 \\
0 \\
0 \\
0\end{array}$ & $\begin{array}{l}0 \\
2 \\
0 \\
i \\
n\end{array}$ & $\begin{array}{l}\stackrel{\circ}{+} \\
\stackrel{+}{+} \\
\stackrel{m}{0}\end{array}$ & 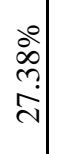 & $\begin{array}{l}0 \\
8 \\
0 \\
8 \\
8\end{array}$ & 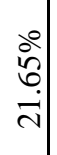 & 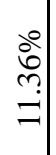 & 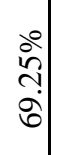 & $\begin{array}{l}\stackrel{0}{\circ} \\
\stackrel{+}{ \pm}\end{array}$ & 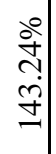 & 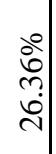 & $\begin{array}{l}\stackrel{0}{0} \\
\stackrel{?}{+} \\
\stackrel{\sim}{v}\end{array}$ & 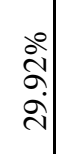 & $\frac{0}{a}$ & 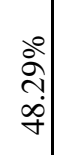 \\
\hline $\begin{array}{l}\dot{3} \\
\dot{3}\end{array}$ & $\begin{array}{l}0 \\
0 \\
\vdots \\
=\end{array}$ & 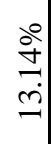 & $\begin{array}{c}\stackrel{0}{a} \\
\stackrel{+}{\dot{c}}\end{array}$ & $\begin{array}{l}\frac{0}{2} \\
\stackrel{n}{m}\end{array}$ & $\begin{array}{l}\stackrel{0}{7} \\
\dot{y} \\
=\end{array}$ & $\begin{array}{l}\stackrel{0}{0} \\
\dot{0} \\
+ \\
+\end{array}$ & 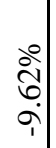 & $\begin{array}{l}0 \\
0 \\
0 \\
0 \\
0\end{array}$ & $\begin{array}{l}\stackrel{\circ}{a} \\
\stackrel{ \pm}{ \pm}\end{array}$ & $\begin{array}{c}0 \\
\stackrel{0}{0} \\
\dot{a} \\
1\end{array}$ & $\begin{array}{l}0 \\
\vdots \\
0 \\
0\end{array}$ & $\begin{array}{l}0 \\
+ \\
+ \\
+ \\
+\end{array}$ & 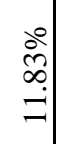 & $\begin{array}{l}\stackrel{0}{\infty} \\
\stackrel{\infty}{=} \\
=\end{array}$ & $\begin{array}{l}00 \\
0 \\
0 \\
i \\
1\end{array}$ \\
\hline 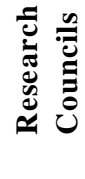 & \begin{tabular}{l}
00 \\
$\infty$ \\
$n$ \\
\hdashline
\end{tabular} & 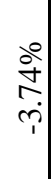 & $\begin{array}{l}0 \\
\\
0 \\
1\end{array}$ & 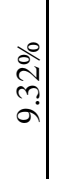 & $\begin{array}{l}\stackrel{0}{2} \\
\stackrel{2}{\lambda} \\
\end{array}$ & $\begin{array}{l}\stackrel{0}{0} \\
\stackrel{0}{+} \\
+\end{array}$ & $\begin{array}{l}0 \\
\dot{0} \\
\dot{p} \\
1\end{array}$ & 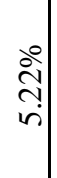 & $\begin{array}{l}80 \\
8 \\
+ \\
\dot{0} \\
\end{array}$ & 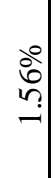 & 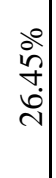 & 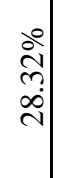 & $\begin{array}{l}0 \\
\vdots \\
\vdots \\
a \\
a\end{array}$ & $\begin{array}{l}0 \\
\vdots \\
\vdots \\
\vdots\end{array}$ & $\begin{array}{l}00 \\
\infty \\
0 \\
0\end{array}$ \\
\hline 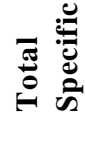 & $\begin{array}{l}\stackrel{0}{0} \\
\hat{\sigma} \\
\dot{+}\end{array}$ & $\begin{array}{l}0 \\
\grave{0} \\
\dot{m}\end{array}$ & 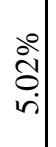 & 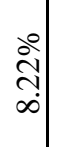 & $\begin{array}{l}0 \\
0 \\
0 \\
0 \\
\dot{ \pm}\end{array}$ & 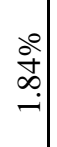 & $\begin{array}{l}\stackrel{0}{0} \\
\stackrel{-}{\Xi}\end{array}$ & 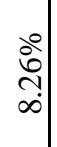 & $\begin{array}{l}0 \\
\vdots \\
\vdots \\
0\end{array}$ & 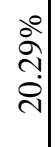 & $\begin{array}{l}\stackrel{0}{0} \\
\stackrel{n}{=} \\
=\end{array}$ & $\begin{array}{l}00 \\
5 \\
\vdots \\
0\end{array}$ & $\begin{array}{l}0 \\
0 \\
0 \\
0 \\
0\end{array}$ & $\begin{array}{l}0 \\
i \\
i \\
i \\
\end{array}$ & $\begin{array}{l}\frac{0}{0} \\
m \\
m\end{array}$ \\
\hline 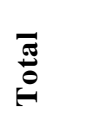 & $\begin{array}{l}0 \\
0 \\
0 \\
0 \\
1\end{array}$ & $\begin{array}{l}0 \\
0 \\
0 \\
0\end{array}$ & $\begin{array}{l}0 \\
0 \\
0 \\
\\
i\end{array}$ & $\begin{array}{l}0 \\
\infty \\
\infty \\
0 \\
1\end{array}$ & 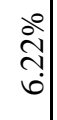 & 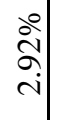 & $\begin{array}{l}0 \\
\infty \\
\infty \\
i\end{array}$ & $\begin{array}{l}0 \\
\dot{n} \\
\infty \\
\dot{n}\end{array}$ & $\begin{array}{l}0 \\
\dot{0} \\
\stackrel{0}{0} \\
i\end{array}$ & 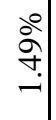 & $\begin{array}{l}0 \\
\dot{0} \\
\infty \\
i\end{array}$ & $\begin{array}{c}\stackrel{0}{+} \\
\stackrel{f}{+} \\
\dot{n}\end{array}$ & $\begin{array}{l}0 \\
\vdots \\
\infty \\
\infty\end{array}$ & $\begin{array}{c}0 \\
\stackrel{0}{0} \\
\stackrel{+}{+}\end{array}$ & $\begin{array}{l}00 \\
\stackrel{0}{0} \\
+ \\
+\end{array}$ \\
\hline$\underset{\nu}{\tilde{\Xi}}$ & $\begin{array}{l}\bar{a} \\
\grave{\partial} \\
\grave{\vdots} \\
\grave{a} \\
\infty\end{array}$ & 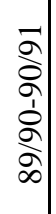 & 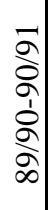 & 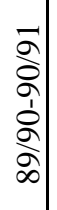 & 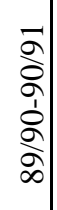 & 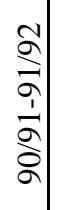 & 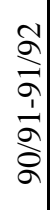 & 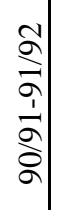 & 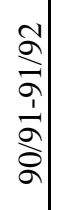 & 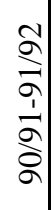 & 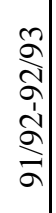 & 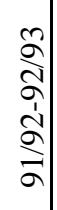 & 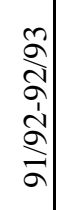 & $\begin{array}{l}\Omega \\
\hat{a} \\
\vdots \\
\vdots \\
\vdots \\
a \\
\sigma\end{array}$ & 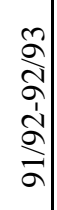 \\
\hline & 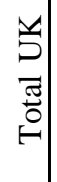 & 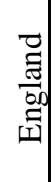 & $\begin{array}{l}\frac{3}{\pi} \\
\frac{3}{3}\end{array}$ & 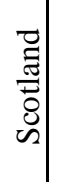 & $\begin{array}{c}\vec{\Xi} \\
\stackrel{\Xi}{0} \\
\stackrel{0}{\Xi} \\
z \\
z\end{array}$ & 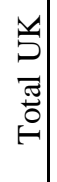 & 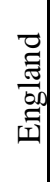 & $\begin{array}{c}\frac{0}{\pi} \\
3\end{array}$ & 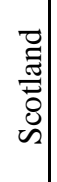 & $\begin{array}{c}\vec{\Xi} \\
\underline{\Xi} \\
\bar{D} \\
\dot{\Xi} \\
\dot{z}\end{array}$ & 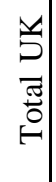 & 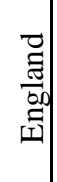 & $\begin{array}{c}0 \\
\frac{0}{\pi} \\
3\end{array}$ & 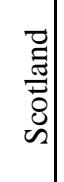 & 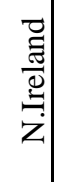 \\
\hline
\end{tabular}


five institutions with the highest value of funds received are the same for each period in the case of Research Council awards, and are only slightly varying in the case of EU. From this observation, it is possible to endorse the idea of funding stability for the top recipients of funding from both sources ${ }^{44}$. It is intriguing to notice that while for some institutions, such as Oxford and Edinburgh, this stability is mainly due to the large size of the institution in all dimensions (see Total Recurrent incomes), whereas for other institutions, such as Imperial College, this is due to their research orientation and their correspondingly higher funding from research sources. Third, the institutions that score better in the ranking of EU, RC and TOTAL funds tend to be similar. Thus, at least for the top institutions, it would seem that EU and national funding criteria are overlapping.

The previous analysis enables us to highlight the fact that on the one hand Research Council funding has shown a mainly negative trend while the EU has realized a significant increase, while on the other hand, both Research Council and EU have focused their top support effort on a similar group of institutions. Therefore, at this level of analysis in not possible to detect clearly the presence or absence of additionality mechanisms.

\subsection{The department analysis}

The aggregate analysis has enabled us to highlight the principal trends revealed in the period being examined. However, to better understand the possible connection between EU source and Government source in university research funding we decided to carry out a field study. In particular, we maintain that, due to the new market oriented internal structure of the university, it is most relevant to focus our analysis on the department/research centre. Indeed, we think that to understand the interaction among different funding sources we need to analyze the mechanisms at work at the department level. Nevertheless, the university as a whole remains the main actor, whose behaviour we want to explain. The focus on the research centre is then justified by the need to identify the micro-mechanisms that can explain the conduct of the complete institution and not by the interest of explaining the functioning of the department itself.

The following analysis focuses on those departments involved in the two BRITE/EURAM (B-E) programmes. We have taken into account only Materials Technology, Material Science and Engineering departments. ${ }^{45}$ Thus, we can maintain that each university has only one of the three departments. We can then consider the number

44 This observation is also true for the Government Bodies component.

45 These are the three research units that have taken part most frequently into B-E programmes. 
of old universities as our population of reference. We have surveyed a sub-sample of 16 departments. They represent the $40 \%$ of the old universities present in the B-E programmes, and they account for the 55\% of the participation (95). It is thus a meaningfully large sample. We have selected them according to the financial dimension of their university (8 Large, 6 Medium and 2 Small) and according to their regional location (13 England, 2 Wales and 1 Scotland). We have conducted telephone interviews with the head of the department, and also have asked the subject to provide responses in writing to a written questionnaire. ${ }^{46}$ Of 20 departments contacted, 16 responded to both the telephone interview and the written survey. The average budget of the respondents was about $£ 2.4 \mathrm{M}$ with a lowest extreme of $£ 0.65 \mathrm{M}$ and a highest extreme of $£ 4 \mathrm{M}$. We have classified them as Small and Medium Departments (SMD) if their annual budget is below then $£ 2.9 \mathrm{M}$ and as Large Department (LD) overwise. The following observations are based on the responses of these 16 surveyed departments.

First, the presence of cumulative and self-reinforcement phenomena emerges clearly from both interviews and questionnaires. These are due to the so-called "Matthew effect". ${ }^{47}$ Research groups that are successful in finding external funding for their research have a higher probability of producing publishable research, which improves their probability of getting funds in the future. When we apply this concept to the EU funding process, we are able to highlight the presence of a specific "path dependent" additionality mechanism at work. Success in obtaining funds from the EU enhances the ability to raise research money in the future from that and other sources. This is due to four micromechanisms. They are:

1. The level of equipment funding that the department receives from the central administration of the university depends in part upon the value of their external research contracts. EU contracts have a particularly significant weight.

2. The ability to obtain EU funds is regarded as critical for the assignment of high rank in the UK's Research Assessment Exercise. Thus, it affects the share of funds for research received by the university from the Exchequer Grant source of funds.

3. The international character of the competition for EU funds, and therefore the high quality of the participants, improves the reputations of the winners. Obtaining EU

\footnotetext{
46 See the annexed telephone questions and questionnaire (Annex B).

47 For an economic analysis of the so-called "Matthew effect" and its implications for resource allocation see David (1994). For its original definition in the sociology of science see Merton (1968).
} 
funds is reputation-building, which increases the probability that winning institutions will receive future funding.

4. Network creation via EU cooperative projects enables the department/university to form a stable cooperation with industrial partners, and that provides a means to generate projects which increase future funding.

The relevance of these micro-mechanisms is confirmed by the results of the survey. In particular, EU funds receipt were judged to have a positive influence on EU sources by $79 \%$ of the respondents; $57 \%$ of the respondents also said there was a positive effect on industry sources of funding. In the case of Government Funds, in general, the impact is a bit less important, perhaps because the Research Assessment Exercise is relatively new as are the internal university negotiations about the departmental distribution of funds received by the university. Thus only $36 \%$ of the responses note a positive influence, while $64 \%$ claimed there was no influence on UK government funding.

Second, when we checked for the presence of substitution effects --i.e. an increase of funds from one source is linked to a decrease of funds from another, that is to say nonadditionality of the various sources-- $63 \%$ of all of the responses indicated they experienced no such substitution. However, if we break down the responses by university and by department size we find that:

-- $\quad 57 \%$ of small and medium sized departments in small and medium universities notice some form of substitution;

-- $\quad 71 \%$ of the large departments in large universities do not notice any form of substitution.

Thus, the funding policy followed by the government appears to be influenced by the size of the department and university, implying the selective application of substitution in a manner that favours the already major research performers.

Third, the impact of government funding policy, and its interaction with the EU funding system, can be better understand when we look at the process of diversification -i.e. moving from fewer main sources of funds to more and different funding sources. In particular the results of the survey allow the following observations:

1. Overall, $56 \%$ of the answers indicate an increase of the annual budget and no one indicates a decrease. However, a somewhat smaller number of the small and medium departments (SMDs) indicate increases rather than no change. 
2. There has been an increase of EU funds in all the departments surveyed. Its growth is particularly important for SMDs.

3. The Research Council funds have tended to decrease, generally, but the effect is more notable among the SMDs.

4. Industry funds have shown a positive growth in large departments and/or large universities, whereas they have decreased in SMDs and/or small and medium universities.

5. The Exchequer Grant has been cut in all the departments without distinction as to the dimension of the department budgets.

If we take the size of the budget of the department as proxy for its quality, and the same dimension of the university as a proxy for its political power, we can maintain that, on the one hand, UK government policy tends to support additionality only for a small group of high quality/politically strong departments/universities. On the other hand, SMDs, mainly when located in small and medium universities, are obliged to rely for their research money to a larger extent on EU funds which are more broadly distributed across universities. Furthermore, due to the recent economic recession, business enterprises have cut external funds for research, and high quality departments or universities with long lasting industrial relationships have strengthened their advantage in obtaining contract and grants from industry.

To conclude, first of all, we have highlighted a set of mechanisms that, by their intrinsic nature, are reinforcing the research and grant-servicing capabilities of the players that are in the game. They also increase the cost --i.e. the required quality-- that a potential new entrant has to pay to gain access to funding. As we have underlined, however, the group of players is quite large compare to the total population --i.e. the EU policy tends to spread research opportunities across many institutions. It also seems highly likely that small and medium sized departments, mainly when they are part of a small or medium university, are suffering funding substitution, while for large departments EU funds seem to be accompanied by substantial funds from the UK government.

Whether or not the overall impact of UK government research policies regarding the universities gives rise to the substitution of EU funds for national resources, or has the opposite result (of providing additionality) will be an outcome of criteria applied in pursuit 
of other objectives, rather than a consequence of conscious, deliberate government policy directions. The promotion of greater stratification among HEI with regard to the conduct of research may favour additionality as an outcome of strengthening the already large and elite research institutions. Or, by further handicapping the smaller institutions and weakening them in their ability to compete for funding from government and industry, it might produce such a contraction as to yield, over time, unambiguous evidences of substitution. 


\section{Conclusions}

The objective of this report is to provide a detailed analysis of the role of "additionality" in the RTD funding activities of the Economic Union. In the opening section of the report we note that the problem of evaluating additionality is complicated by many factors including the absence of a clear boundary in the outcomes of EU and member state funding to specific institutions, practical difficulties of establishing a base of member state RTD funding by which to evaluate substitution of EU funding for member state funding, and the possibility that substitution relationships may exist within member states at the level of specific research institutions.

We have examined the aggregate statistics on EU RTD funding at the level of the member state and by programme within the Second and Third Frameworks. We find that there are similar patterns of concentration between EU and member state funding at both these levels of aggregation. This conclusion indicates that patterns of research specialization may be similar for both EU and member state RTD funding. We have also tested two behavioural hypotheses about the practice of substitution of EU for member state RTD investments. The results of these tests indicate that substitution is neither a systematic or pervasive characteristic of member state response to the receipt of EU funds for the behavioural hypotheses chosen (contemporaneous and lagged response).

Pursuing the possibility of substitution relationships at a lower level of aggregation for one member state, the United Kingdom, and one programme Brite-EURAM we find that for larger institutions of higher education that EU and national funding are likely to be complementary while for smaller universities and university departments there are indications that substitution is important.

Several areas for more extensive research have been suggested including broadening the analysis conducted here from a single programme and member state, examining the budgetary practices of member states to detect how their fiscal control systems treat EU funding, and more deeply investigating the unintended consequences in EU funding that might occur as the result of reinforcing mechanisms such as the "Matthew Effect." 


\section{Annex (A): EU, Research Council and Total Income to UK Universities.}

European Community income $(£ 000$ in $1986 \mathfrak{f})$ :

EC - 1990/91

Valid cases: $\quad 74$

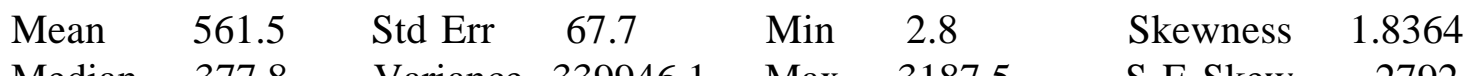

$\begin{array}{lllllll}\text { Median } & 377.8 & \text { Variance } & 339946.1 & \text { Max } & 3187.5 & \text { S E Skew }\end{array}$

10 Highest UNIVERSITIES

$\begin{array}{llll}3187.5 & \text { University College } & 1549.9 & \text { Leicester } \\ 1951.5 & \text { Imperial College } & 1532.3 & \text { Southampton } \\ 1804.8 & \text { Liverpool } & 1280.2 & \text { Cambridge } \\ 1659.4 & \text { Oxford } & 1245.1 & \text { Strathclyde } \\ 1651.7 & \text { Edinburgh } & 1173.5 & \text { Newcastle }\end{array}$

EC - 1991/92

Valid cases: $\quad 74$

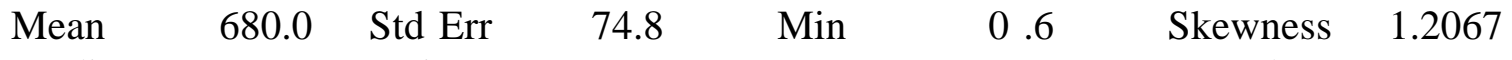

$\begin{array}{lllllll}\text { Median } & 527.8 & \text { Variance } & 414112.1 & \text { Max } & 2809.7 & \text { S E Skew }\end{array}$

10 Highest UNIVERSITIES

$\begin{array}{llll}2809.7 & \text { Imperial College } & 1559.7 & \text { Strathclyde } \\ 2565.0 & \text { University College } & 1556.4 & \text { Oxford } \\ 2253.9 & \text { Queen's University } & 1478.3 & \text { Edinburgh } \\ 1934.4 & \text { University of Ulster } & 1467.2 & \text { Aberdeen } \\ 1914.0 & \text { Liverpool } & 1401.6 & \text { Leicester }\end{array}$


EU - 1992/93

Valid cases: $\quad 74$

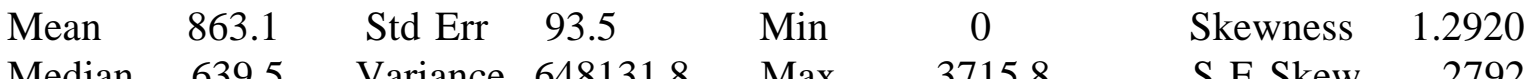

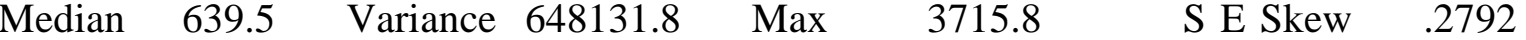

10 Highest UNIVERSITIES

$\begin{array}{llll}3715.9 & \text { Queen's University } & 2196.5 & \text { University College } \\ 3367.3 & \text { Imperial College } & 1990.0 & \text { Edinburgh } \\ 2495.0 & \text { University of Ulster } & 1842.9 & \text { Oxford } \\ 2378.6 & \text { Cambridge } & 1784.7 & \text { Newcastle } \\ 2305.4 & \text { Liverpool } & 1747.2 & \text { Aberdeen }\end{array}$


Research Council income ( $£ 000$ in $1986 £$ ):

RC - 1990/91

Valid cases: $\quad 74$

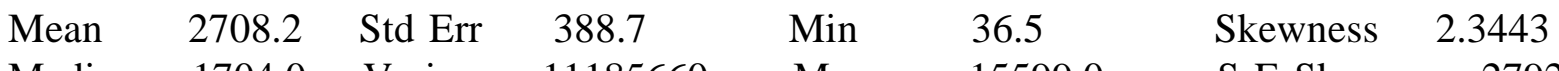

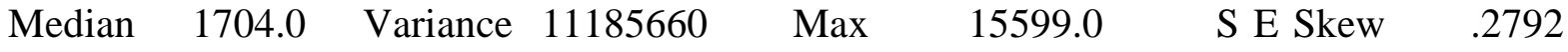

10 Highest UNIVERSITIES

$\begin{array}{clll}15599.0 & \text { Oxford } & 7964.2 & \text { Glasgow } \\ 13547.8 & \text { Cambridge } & 6198.0 & \text { Birmingham } \\ 13421.3 & \text { Imperial College } & 6097.6 & \text { Manchester University } \\ 13417.8 & \text { Edinburgh } & 5998.6 & \text { Liverpool } \\ 9907.3 & \text { University College } & 5751.4 & \text { Southampton }\end{array}$

RC - 1991/92

Valid cases: $\quad 74$

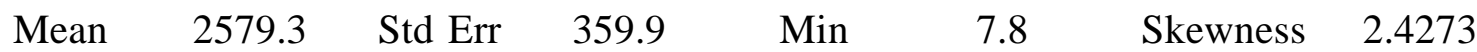

$\begin{array}{lllllll}\text { Median } & 1778.2 & \text { Variance } & 9586344 & \text { Max } & 15341.2 & \text { S E Skew }\end{array}$

10 Highest UNIVERSITIES

$\begin{array}{llll}15341.2 & \text { Oxford } & 7094.5 & \text { Glasgow } \\ 13915.4 & \text { Cambridge } & 6029.5 & \text { Birmingham } \\ 11440.3 & \text { Imperial College } & 5353.0 & \text { Manchester University } \\ 10477.0 & \text { University College } & 4967.8 & \text { Liverpool } \\ 10325.5 & \text { Edinburgh } & 4874.7 & \text { Southampton }\end{array}$


RC - 1992/93

Valid cases: $\quad 74$

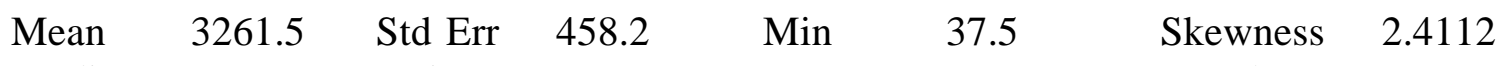

$\begin{array}{lllllll}\text { Median } & 2023.7 & \text { Variance } & 15539934 & \text { Max } & 19433.6 & \text { S E Skew }\end{array}$

10 Highest UNIVERSITIES

$19433.7 \quad$ Oxford

18142.1 Cambridge

$14004.4 \quad$ University College

13879.2 Imperial College

$11875.5 \quad$ Edinburgh
8560.1 Glasgow

7976.2 Birmingham

7630.2 Manchester University

6517.5 Southampton

6279.1 Liverpool 
Total recurrent income ( $£ 000$ in $1986 £$ ):

TOTAL - 1990/91

Valid cases: $\quad 74$

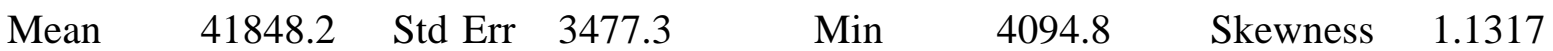

$\begin{array}{lllllll}\text { Median } & 32604.2 & \text { Variance } & 8.95 E+08 & \text { Max } & 127373.6 & \text { S E Skew }\end{array}$

10 Highest UNIVERSITIES

$\begin{array}{llll}\text { 127373.6 } & \text { Oxford } & 98653.1 & \text { University College } \\ 115047.1 & \text { Cambridge } & 94368.0 & \text { Imperial College } \\ 113451.5 & \text { Edinburgh } & 91469.8 & \text { Leeds } \\ 112983.8 & \text { Manchester University } & 89872.2 & \text { Birmingham } \\ 100346.2 & \text { Glasgow } & 79819.5 & \text { Liverpool }\end{array}$

TOTAL - 1991/92

Valid cases: $\quad 74$

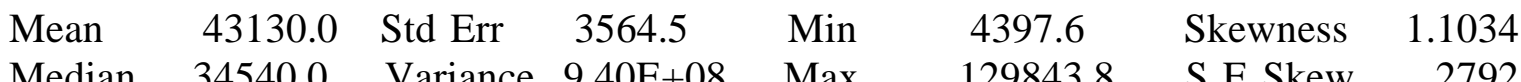

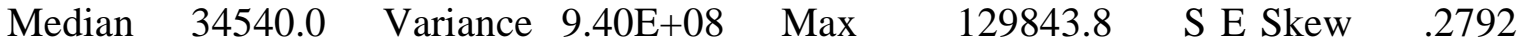

10 Highest UNIVERSITIES

$\begin{array}{llll}129843.8 & \text { Oxford } & 101851.0 & \text { University College } \\ 119559.1 & \text { Cambridge } & 95062.3 & \text { Imperial College } \\ 116059.7 & \text { Manchester University } & 94403.5 & \text { Leeds } \\ 110470.5 & \text { Edinburgh } & 93300.5 & \text { Birmingham } \\ 103837.3 & \text { Glasgow } & 81895.7 & \text { Liverpool }\end{array}$


TOTAL - 1992/93

Valid cases: $\quad 74$

$\begin{array}{lclllclr}\text { Mean } & 45657.4 & \text { Std Err } & 3765.6 & \text { Min } & 4413.0 & \text { Skewness } & 1.0876 \\ \text { Median } & 35806.9 & \text { Variance } & 1.05 E+09 & \text { Max } & 133092.0 & \text { S E Skew } & .2792\end{array}$

10 Highest UNIVERSITIES

$\begin{array}{llll}133092.0 & \text { Oxford } & 102150.2 & \text { University College } \\ 130217.1 & \text { Cambridge } & 98088.1 & \text { Birmingham } \\ 123921.2 & \text { Manchester University } & 98271.6 & \text { Leeds } \\ 119587.6 & \text { Edinburgh } & 96610.8 & \text { Imperial College } \\ 108853.6 & \text { Glasgow } & 88592.0 & \text { Liverpool }\end{array}$




\section{Annex (B): Telephone interviews and questionnaire.}

Telephone interview, four questions:

First , How have the sources of funds for research changed over time in your department? ..

Second, Is there some kind of positive or negative interrelation among the various sources of funds?

..

Third, What type of research expenditure have been most influenced by recent funding patterns.

..

Fourth, Can you say something specific on the role played by the EU funds? 
Questionnaire:

\section{MERIT survey on university funding}

This survey is part of a broader research project that MERIT (Maastricht Economic Research Institute on Innovation and Technology) is carrying out for the European Parliament. The answers to the survey will be treated with the usual criterion of anonymity of the interviewee.

This form and the attached comments, if any, are to be faxed back to the following number: +31 43216518 - to the attention of Aldo Geuna.

We thank you for you help.

\section{QUESTION 1}

The annual survey on university financing, published by the Universities' Statistical Record, identifies a certain number of income sources. At the most aggregate level the break down is among the seven classes we use below.

How important are the following sources/classes for the total funding of your department this year? (Circle your choice)

Unimportant

1. Exchequer Grant

2. Research Council

3. Government contracts and services

4. EU contracts and services

5. Industry contracts and services

6. Fees

7. Others

$\begin{array}{lllll}1 & 2 & 3 & 4 & 5 \\ 1 & 2 & 3 & 4 & 5 \\ 1 & 2 & 3 & 4 & 5 \\ 1 & 2 & 3 & 4 & 5 \\ 1 & 2 & 3 & 4 & 5 \\ 1 & 2 & 3 & 4 & 5 \\ 1 & 2 & 3 & 4 & 5\end{array}$

Extremely Important

5 5 5 5 5 5 5 


\section{QUESTION 2}

Do you think that in recent years (1990-1993) the funding structure of the department has undergone a process of diversification (Diversification: moving from fewer main sources of funds to more and different funding sources)? (Circle your choice)

$$
\text { YES NO }
$$

If yes, how important was the change (growth or contraction) of the following classes in the years 1990-1993? (Circle positive (+) or negative (-) to indicate diversification change)

\section{Unimportant}

1. Exchequer Grant

2. Research Council

3. Government contracts and services

4. EU contracts and services

5. Industry contracts and services

6. Fees

7. Others

$\begin{array}{llll}+ & - & 1 & 2 \\ + & - & 1 & 2 \\ + & - & 1 & 2 \\ + & - & 1 & 2 \\ + & - & 1 & 2 \\ + & - & 1 & 2 \\ + & - & 1 & 2\end{array}$

\section{Extremely} Important

5

5

5

5

5

5

5

\section{QUESTION 3}

Have you noted some form of substitution (Substitution: an increase of funds from one source is linked to a decrease of funds from another) among the various form of funding in your department in recent years (1990-1993)? (Circle your choice)

YES NO

If yes, do you agreeldisagree that the following forms of substitutions have occurred?

Strongly

Agree

1. Fees have substituted Exchequer Grant

2. EU contract and services have substituted Research Council

3. EU contract and services have substituted Government contract and services

4. Industry contract and services have substituted Research Council

5. Industry contract and services have substituted Government contract and services

6. Research Council has substituted Exchequer Grant

7. Others. (Specify which and how important)
Strongly

Disagree

$\begin{array}{lllll}1 & 2 & 3 & 4 & 5\end{array}$

$1 \quad 2 \quad 3 \quad 4 \quad 5$

$\begin{array}{llll}1 & 2 & 3 & 4\end{array}$

$\begin{array}{llll}1 & 2 & 3 & 4\end{array}$

5

$\begin{array}{lllll}1 & 2 & 3 & 4 & 5\end{array}$

$\begin{array}{lllll}1 & 2 & 3 & 4 & 5\end{array}$




\section{QUESTION 4}

Do you think that EU funds receipt has had either a positive or a negative influence on the following funding sources? (Circle your choice)

1. Exchequer Grant

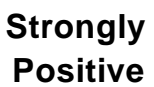

2. Research Council

3. Government contracts and services

4. EU contracts and services

5. Industry contracts and services

6. Fees

7. Others

\section{Positive}

1

1

1

1

1

1

1

$\begin{array}{cccc} & \text { No Influence } & \begin{array}{c}\text { Strongly } \\ \text { Negative }\end{array} \\ 2 & 3 & 4 & 5 \\ 2 & 3 & 4 & 5 \\ 2 & 3 & 4 & 5 \\ 2 & 3 & 4 & 5 \\ 2 & 3 & 4 & 5 \\ 2 & 3 & 4 & 5 \\ 2 & 3 & 4 & 5\end{array}$

\section{QUESTION 5}

Could you please give us an estimate of the annual budget of your department including total salaries and other costs?

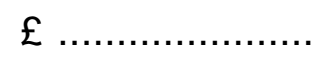

Has this value changed in the last four to five years? (Circle your choice)
a) Increased
b) Decreased
c) No Change

Could you please tell us the number of BRITE-EURAM projects in which your department has been involved? 


\section{Annex (C): List of Framework Programmes taken into account.}

Second Framework:

HUMAN GENOME

RADIATION PROTECTION

STEP/EPOCH

AIM

ESPRIT

BRITE/EURAM

AERONAUTICS

RAW MATERIALS

BRIDGE

COORDINATION OF AGRICULTURAL RESEARCH

ECLAIR

FAIR

DECOMMISSIONING

JOULE

RADIOACTIVE WASTE

TELEMAN

SCIENCE AND TECHNOLOGY FOR DEVELOPMENT

FAR

MAST

No data was available for RACE and EUROTRA, consequently DRIVE and EURET were the only two programmes available for NABS Chapter 2 (Infrastructure and general planning of land-use). Thus, Chapter 2 has not been included in our analysis. The programmes DELTA, DOSES, LARGE FACILITIES, SCIENCE and SPES have not been included in our analysis due to the general character of NABS Chapter 8 (Social structures and relationships) and NABS Chapter 11( Non-oriented research) under which they are classified. MEDICAL AND HEALTH, BCR, FUSION, MONITOR and VALUE were not included due to the special nature of the programmes.

Third Framework:

INFORMATION TECHNOLOGY

TELEMATIC SYSTEM

INDUSTRIAL AND MATERIAL TECHNOLOGIES

AERONAUTICS

MEASUREMENT AND TESTING

ENVIRONMENT

MARINE SCIENCE AND TECHNOLOGY 
BIOTECHNOLOGY

AGRICULTURE AND AGRO-INDUSTRY

BIOMEDICINE AND HEALTH

LIFE SCIENCES AND TECHNOLOGIES FOR DEVELOPING COUNTRIES

NON-NUCLEAR ENERGIES

NUCLEAR FISSION SAFETY

No data was available for COMMUNICATIONS TECHNOLOGY. FUSION and HUMAN CAPITAL AND MOBILITY were not included in our analysis due to the special nature of the programmes. Parts of programmes related to NABS Chapters 2, Chapter 8 and Chapter 11 were excluded since these chapters were not analysed. 


\section{References}

Commission of the European Communities, 1994a, The European Report on Science and Technology Indicators 1994, Report EUR 15897 EN.

Commission of the European Communities, 1994b, Report to the European Council on the Application of the Subsidiarity Principle, COM (94), 533.

Commission of the European Communities, 1994c, Research and Technological Development Achieving Coordination Through Cooperation, COM (94), 438.

Commission of the European Communities, 1993a, Catalogue of Research Projects in the Third Framework, Report EUR 14937 EN.

Commission of the European Communities, 1993b, Working Document of the Commission Concerning the S\&T content of the Specific Programmes Implementing the 4th Framework Programme for Community Research and Technological Development (1994-1998) and the Framework Programme for Community Research and Training for the European Atomic Energy Community (1994-1998), COM (93) 459.

Commission of the European Communities, 1993c, Evaluation of the BRITE/EURAM programme (1989 - 1992) - (areas 1 to 4), Report EUR 15070 EN.

Commission of the European Communities, 1993d, Economic Evaluation of the Effects of the BRITE/EURAM Programmes on the European Industry, Report EUR 15171 EN.

Commission of the European Communities, 1993e, Second Commission Working Document Concerning RTD Policy in the Community and the Fourth Framework Programme (1994-1998) of Community RTD Activities, COM (93) 158.

Commission of the European Communities, 1993f, NABS. Nomenclature for the Analysis and Comparison of Scientific Programmes and Budget, Eurostat 9/1993.

Commission of the European Communities, 1992a, EC Research Funding. A Guide for Applicants.

Commission of the European Communities, 1992b, Evaluation of the Second Framework Programme for Research and Technological Development, SEC (92) 675. 
Commission of the European Communities, 1986, NABS, Nomenclature for the Analysis and Comparison of Scientific Programmes and Budget, Eurostat 7/1986.

Contzen, J., 1991, European Integration and University Research: an Overview, Higher Education Management, Vol. 3 No. 2, pp. 137-144.

Cox, A., 1994, Derogation, Subsidiarity and the Single Market. The Case of Energy Exploration and Extraction under the EU Utilities Procurement Rules, Journal of Common Market Studies, Vol. 32, No. 2, pp. 126-147.

Dasgupta, P. and David, P.A., 1994, Toward a New Economics of Science, Research Policy, 23:487-521.

David, P.A., 1994, Positive Feedbacks and Research Productivity in Science: Reopening Another Black Box in Economics and Technology, in O. Granstraad (ed.), Economics of Technology, Amsterdam: Elsevier Science Publishers.

Garcia, W. and Geuna, A., 1994, The Dynamics of Network Formation, the Case of BRITE/EURAM, prepared for the conference "New Research Findings: The Economics of Scientific and Technological Research in Europe", University of Urbino, 24-25 February, 1995.

Georghiou, L. et al., 1993, The Impact of European Community Policies for Research and Technological Development Upon Science and Technology in the United Kingdom, Report prepared for the DGXII of the Commission of the European Communities and for the Office od Science \& Technology, London, HMSO..

Hanham, H.J., 1991, The Funding of University Research. The Role of Overheads, Higher Education Management, Vol. 3 No. 2, pp 107-113.

HMSO, 1993, Realising our potential. A strategy for Science, Engineering and Technology.

HMSO, 1992, Higher Education. A New Framework.

HMSO, 1990, Education Reform Act 1988 Chapter 40.

House of Lords, Select Committee on the European Communities, 1990, A community Framework for $R \& D$, HMSO, London.

Hurst, E.R., 1991, Cost Calculation and Cost Management of Multinational Research Projects, Higher Education Management, Vol. 3 No. 2, pp 114-127.

HEFCE, Annual Report 1992-93, 1993-94. 
Kaiser, F. et al., 1992, Public Expenditure on Higher Education: a Comparative Study in the EC-Member States, 1975-1990, Higher Education in Europe, Vol. XVII No. 1, pp. 3364.

Kersbergen van, K., Verbeek, B., 1994, The policy of Subsidiarity in the European Union, Journal of Common Market Studies, Vol. 32, No. 2, pp. 215-236.

Merton, R.K., 1968, The Matthew Effect in Science, Science, 159 (3810), January 5, pp. 56-63.

OECD, 1987, Universities under Scrutiny, OECD, Paris.

OECD, 1990, Financing Higher Education. Current Patterns, OECD, Paris.

Peters, M., 1992, Performance and Accountability in 'Post-industrial Society': the crisis of British universities, Studies in Higher Education, Vol. 17 No. 2, pp. 123-139.

Soete, L. and Arundel, A. (eds.), 1993, An Integrated Approach to European Innovation and Technology Diffusion Policy: A Maastricht Memorandum, SPRINT, Commission of the European Communities, Publication no. EUR 15090, May.

Webster, A., 1994, UK Government's White Paper (1993): A Critical Commentary on Measures of Exploitation of Scientific Research, Technology Analysis \& Strategic Management, Vol.6, No. 2, pp. 189-201.

The Times Higher Education Supplement, Various issues.

Universities' Statistical Record, University Statistics. Vol. 1 Students and Staff, Various issues.

Universities' Statistical Record, University Statistics. Vol. 3 Finance, Various issues.

Weghtman, P., 1991, Collaborative Scientific Research in a European Context. A University of Liverpool Case Study, Higher Education Management, Vol. 3, No. 2, pp.145-153.

Williams, G., 1992a, Changing Patterns of Finance in Higher Education, The Society for Research into Higher Education \& Open University Press, Buckingham.

Williams, G., 1992, An Evaluation of the New Funding Mechanisms in British HigherEducation: Some Micro-Economic and Institutional Management Issues, Higher Education in Europe, Vol. XVII No. 1, pp. 64-85. 